\title{
Cinema e religião: teorias de processos recursivos e de transformações
}

\author{
Giovanni Felipe Catenaci* \\ Paulo Augusto de Souza Nogueira**
}

\section{Resumo}

Este artigo tem por objetivo sustentar a plausibilidade da seguinte hipótese: as imagens religiosas presentes no cinema de Sergei Eisenstein são elementos poderosos no sentido de nos fazer pensar e agir diferente. Para tanto, nossos esforços concentrar-se-ão em dois sentidos principais. Em um primeiro momento vamos a busca de fundamentar teoricamente a apropriação de Gilles Deleuze em relação a epistemologia de Henri Bergson. Com isso, importa-nos pavimentar a compreensão dos principais conceitos deleuzeanos, presentes em Cinema I - A imagem-movimento (1983), e em parte Cinema II- A imagem-tempo (1985). Ainda neste primeiro momento, passaremos às análises realizadas por Deleuze sobre o cinema de Eisenstein. Aqui, nosso foco específico é apresentar em linhas gerais, o que o filósofo francês entende por montagem soviética. Desta feita, passaremos a apresentação dos aspectos da reflexão de Eisenstein sobre o cinema e sua relação com as estruturas arcaicas de pensamento, e como isso se alinha ao seu desejo de provocar nos espectadores afetos e disposições desconhecidas. Finalmente, com vistas a reforçar nossa hipótese, investiremos atenção na análise de três filmes $A$ greve (1925), Encouraçado Potemkin (1925), e Que viva México! (1979).

Palavras-chave: cinema; religião; Deleuze; Bergson; Eisenstein.

\section{Cinema and Religion: Theories of Recursive Processes and Transformations}

\section{Abstract}

This paper aims to support the plausibility of the following hypothesis: the religious images present in Sergei Eisenstein's cinema are powerful elements in the sense of

* Doutor em Ciências da Religião pela Universidade Metodista de São Paulo, pesquisador em nível de Pós-Doutorado no Programa em Ciências da Religião da Pontifícia Universidade Católica de Campinas.

** PUC Campinas. Doutor em Teologia pela Universidade de Heidelberg (Ruprecht-Karls), fez estudos pós-doutorais em História no NEE/Unicamp. É professor pesquisador da Pós-graduação em Ciências da Religião da Pontifícia Universidade Católica de Campinas. pasn777@gmail.com . 


\section{Giovanni Felipe Catenaci}

Paulo Augusto de Souza Nogueira

making us think and act differently. To this end, our efforts will focus on two main directions. At first, we seek to theoretically support Gilles Deleuze's appropriation in relation of Henri Bergson's epistemology. With this, it is important to pave the way for the understanding of the main Deleuzian concepts, present in Cinema I - The Movement-Image (1983), and in part Cinema II- The Time-Image (1985). Still in this first moment, we will move on to the analyzes carried out by Deleuze on Eisenstein's cinema. Here, our specific focus is to outline what the French philosopher means by Soviet montage. This time, we will present the aspects of Eisenstein's reflection on cinema and its relationship with archaic thought structures, and how this is aligned with his desire to provoke unknown affections and dispositions in spectators. Finally, in order to reinforce our hypothesis, we will pay attention to the analysis of three films The Strike (1925), Battleship Potemkin (1925), and Que viva Mexico! (1979).

Keywords: cinema; religion; Deleuze; Bergson; Eisenstein.

\section{Cine y religión: teorías de procesos recursivos y transformaciones}

\section{Resumen}

Este artículo pretende apoyar la plausibilidad de la siguiente hipótesis: las imágenes religiosas presentes en el cine de Sergei Eisenstein son elementos poderosos en el sentido de hacernos pensar y actuar de manera diferente. Con este fin, nuestros esfuerzos se centrarán en dos direcciones principales. Al principio, buscamos apoyar teóricamente la apropiación de Gilles Deleuze de la epistemología de Henri Bergson. Con ello, es importante allanar el camino para la comprensión de los principales conceptos deleuzianos, presentes en Cine I - El Movimiento-Imagen (1983), y en parte en Cine II- El Tiempo-Imagen (1985). Aún en este primer momento, pasaremos a los análisis realizados por Deleuze sobre el cine de Eisenstein. Aquí, nuestro enfoque específico es delinear lo que el filósofo francés quiere decir con montaje soviético. En esta ocasión, presentaremos los aspectos de la reflexión de Eisenstein sobre el cine y su relación con las estructuras de pensamiento arcaicas, y cómo esto se alinea con su deseo de provocar en los espectadores afectos y disposiciones desconocidas. Finalmente, para reforzar nuestra hipótesis, prestaremos atención al análisis de tres películas La huelga (1925), El acorazado Potemkin (1925) y ¡Que viva México! (1979).

Palabras clave: cine; religión; Deleuze; Bergson; Eisenstein.

\section{Cinema e pensamento em Gilles Deleuze}

Gilles Deleuze nunca se propôs a fazer teoria do cinema, tampouco história do cinema. Na verdade, movido por um ímpeto taxonômico, para além de pensar o cinema filosoficamente, Deleuze esteve preocupado em investigar como o cinema pensa, e em certa medida também, como ele nos faz pensar. Impossível seria sustentar a plausibilidade de tal problema sem que contasse de antemão com uma dada imagem do que fosse o pensamento. Afinal, antes de responder como pensa o cinema, é necessário dispor de 
uma concepção do que seja o pensar. E é nesse sentido que ele se agenciará a Henri Bergson, filósofo contemporâneo ao surgimento da indústria cinematográfica, e que a despeito de qualquer suspeita, esteve às bailas do debate instaurado pela Sétima Arte. ${ }^{1}$

Através de uma leitura bastante inovadora e complexa - simplesmente impossível de ser reproduzida dentro nos limites deste artigo -, Deleuze partirá da relação estabelecida por ele, entre os modos de funcionamento daquilo que Bergson chama de percepção, e ao maquinário do cinema. Grosso modo para Deleuze, tanto o pensamento funcionaria como uma espécie de cinematógrafo, quanto o cinema atuaria em termos de pensamento. Tal como buscaremos apresentar a seguir de forma respectiva através dos tópicos subsequentes, Deleuze - amparado em Matéria e Memória [1896] de Bergson -, dirá que tanto o pensamento quanto o cinema, se constituem de três níveis específicos: $i$. A unidade mínima de um conjunto fechado, produzido pela percepção como enquadramento; ii. Um plano em movimento sobre o qual a percepção recortaria e montaria seus quadros; e iii. A própria imagem-movimento como expressão do pensamento, que corresponde à montagem.

Não obstante a tudo isso, os esforços preliminares aqui presentes, estarão concentrados em pavimentar uma superfície teórica segura o bastante para sustentar o objetivo deste artigo. A saber, o traçado de uma zona de vizinhança entre as teorias de Gilles Deleuze, o cinema de Sergei Eisenstein e a religião. Em particular, este primeiro tópico, visa apresentar os elementos indispensáveis à compreensão do conceito de patético, disposto por Deleuze em seu livro Cinema I - A imagem-movimento [1983], quando de sua análise da escola de montagem soviética. É com este conceito que prepararemos o caminho à reflexão acerca dos materiais religiosos utilizados por Eisenstein em seus filmes, materiais recursivos, que remetem à origem, não apenas do pensamento, mas também dos reflexos dos organismos, não exclusivamente humanos, uma origem sensorial, base de toda elaboração mito-poética.

Para tanto, passaremos, em primeiro lugar, à explicação dos três tópicos acima referidos, a fim de responder a pergunta deleuzeana sobre como o filme pensa e pode nos faz pensar. Depois, em segundo lugar, retomaremos o dilema de Eisenstein - que lhe foi inquietante até trabalhar em Que Viva México! - de que o filme é composto por dois aspectos indissociáveis, um recursivo, primitivo, sensorial, que se refere à sua forma, e outro progressivo,

1 Ao menos é o que podemos constatar em A evolução criadora, datada de 1907, e onde Bergson irá dedicar todo o último capítulo ao mecanismo cinematográfico do pensamento. 
rumo à transformação, à revolução, que se refere ao conteúdo. (V. V. IVANOV, 181). A transição entre a reflexão de Deleuze e a de Eisenstein se dará na própria obra do primeiro, em sua análise do modo de montagem do cinema soviético. Queremos neste artigo levantar perguntas sobre a relação cinema e religião que busquem transcender os paralelismos e correlações, buscando na percepção e nos modos sensoriais primitivos de pensamento as estruturas que permitem falar de cinema como percepção, como pensamento e como religião.

\section{1 A percepção e o enquadramento}

Em Matéria e Memória (2012), datado originalmente do ano de 1896, Henri Bergson dirá acerca dos organismos vivos que estes são "centros de indeterminação", organizados a partir de uma estrutura sensóriomotora, que no limite, lhes contextualizaria a faculdade da percepção - que conforme veremos, atua por enquadramentos. Em Cinema 1: A imagemMovimento, Deleuze dirá o seguinte: "Chamamos de enquadramento a determinação de um sistema fechado, relativamente fechado, que compreende tudo o que está presente na imagem, cenários, personagens, acessórios" (DELEUZE, 2018, p.29). ${ }^{2}$

Retornando a Bergson, é da indeterminação que ele irá derivar a singularidade de tais seres, que diferente dos outros corpos, por contarem com uma espécie de "espessura intervalar", isto é, uma hesitação entre a sensação de algum movimento, e sua respectiva reação, seriam indeterminados por natureza; por conseguinte, capazes de perceber e agir de formas distintas, a depender da situação. ${ }^{3}$

Todavia a despeito de compartilharem da mesma estrutura "polaridade fendida" -, na medida em que se desenvolvem, os seres vivos

2 Se fazemos questão de citar esse excerto, é justamente por conta de ele apresentar a relação estabelecida por Deleuze quando de sua escrita sobre o cinema. Especificamente, trata-se de reconhecer que a epistemologia de Bergson, serve de pavimentação teórica para Deleuze, desdobrar seus conceitos e teses cinematográficas.

3 Pensemos por exemplo em uma ameba, que ao menor sinal de contato com algo, se retrai quase que imediatamente, em um movimento reflexo. Primeiro a sensação, depois a reação, entre as duas a hesitação - por minúscula que seja neste caso. Estendendo tal analogia aos organismos mais complexos do reino natural, começando pelos vegetais, passando pelos animais não racionais, e chegando enfim aos humanos, encontraríamos a mesma marca da indeterminação; que como dissemos, atua como um tipo de "fratura" em sua configuração sensório-motora. Obviamente, que no caso dos organismos complexos, o tempo de hesitação é bem mais estendido. 
também dispõem de uma margem cada vez maior para a calibragem de sua percepção e movimentos. Ou seja, enquanto avançam em uma escala de complexidade evolutiva, eles gradualmente se tornam mais indeterminados e mais ricos também. ${ }^{4}$ Ainda de acordo com Bergson, essa hesitação no caso dos organismos complexos, teria a ver com o próprio cérebro, que funcionaria como uma espécie de "central telefônica"; cumprindo a função de captação dos estímulos do ambiente e a distribuição das respostas ao corpo, por meio do encaminhamento dos comandos para os órgãos motores respectivos. É por isso que quanto mais comum e corriqueiro for o estímulo, mais ágil a percepção e ação tenderão a ser; afinal, o cérebro engajado em sua missão psicomotora, tenderá a "encurtar os caminhos", investindo menos energia possível neste processo orgânico, preservando-se a cada vez em sua zona de conforto. ${ }^{5}$

Não obstante, Bergson chamará a atenção para o inevitável processo de empobrecimento da percepção e da ação, ocorrido em meio aquilo que ele denomina de reconbecimento habitual das imagens. ${ }^{6}$ Ainda no que se refere a percepção tal como pensada por Bergson, vale destacar os dois principais modos, através dos quais atua a percepção: o instinto e a inteligência. Como duas formas de atividade psíquica diferentes, mas, complementares, instinto e inteligência são qualificados por ele, desde a relação que cada um mantém com os instrumentos. De tal modo, enquanto a faculdade da inteligência tem por traço constitutivo a manipulação e fabricação de instrumentos artificiais e ou inorganizados, o instinto estaria aferrolhado à condição de sempre ter de lidar com instrumentos organizados. De outra forma, "o instinto acabado é uma faculdade de utilizar e mesmo de construir

4 Recorrendo ao modelo da ameba novamente, na qual percepção e reação são movimentos praticamente automáticos, os intervalos sensórios-motores de que gozam um cão, um chimpanzé ou uma criança, são substancialmente maiores como dissemos. Fator este que na prática irá munir tais seres, de percepções e reações mais sensíveis e apuradas.

5 Tal como ocorre quando dirigimos, ou escovamos os dentes pela manhã, ou vagabundeamos pelos feeds de nossas redes sociais... "Sem percebermos" efetuamos uma série de movimentos que demandam pouquíssima ou quase nenhuma reflexão.

6 Em menção a espessura do tempo de hesitação entre o estímulo e a resposta, ele dirá que "nossa existência decorre em meio a objetos em número restrito, que tornam a passar com maior ou menor frequência diante de nós, cada um deles, ao mesmo tempo em que é percebido, provoca de nossa parte movimentos pelos menos nascentes através dos quais nos adaptamos a eles. Esses movimentos, ao se repetirem, criam um mecanismo, adquirem a condição de hábito, e determinam em nós atitudes que acompanham automaticamente nossa percepção das coisas (BERGSON, 2011, p.91). 


\section{Giovanni Felipe Catenaci}

Paulo Augusto de Souza Nogueira

instrumentos organizados; a inteligência é a faculdade de fabricar e de empregar instrumentos inorganizados" (BERGSON, 2019, p.152).7

Por isso é correto dizer que a percepção não se constitui como uma faculdade cujos fins estariam destinados especificamente à tarefa especulativa, mas, ao invés disso, como afirma Bergson, existiria para satisfazer as necessidades orgânicas de um corpo; que percebe para poder agir, sempre e necessariamente. E quanto mais inteligente for o organismo, menor será sua hesitação, mais ágil será sua capacidade de reconhecimento e reação; chegando em certos casos a um verdadeiro automatismo. Nesse sentido, de acordo com nosso filósofo a percepção teria fins muito pouco, ou quase nada teóricos, sendo na realidade caudatária da necessidade orgânica de adaptação dos corpos ao seu meio ambiente.

Isso significa dizer que a percepção inteligente das coisas é invariavelmente redutora do todo aberto no qual os corpos estão inseridos. Isso, pois para agir, a percepção tem de excluir toda uma variedade de outras imagens. Efetuando, portanto, uma descontinuidade e uma imobilidade fortuitas, a percepção não acrescenta nada à realidade. Antes atua no sentido de recortar tudo aquilo que não lhe é interessante do ponto de vista da ação, produzindo desta forma unidades mínimas em um conjunto fechado, chamada quadro. Enfim, conforme explica Bergson "O que é preciso para obter essa conversão não é iluminar o objeto, mas ao contrário, obscurecer certos lados dele, diminuí-lo da maior parte de si mesmo, de modo que o resíduo, em vez de permanecer inserido no ambiente como uma coisa, destaca-se como um quadro"

7 No intuito de clarificar possíveis incompreensões, vejamos a explicação de Bergson que continua a citação acima da seguinte forma: "As vantagens e os inconvenientes desses dois modos de atividade saltam aos olhos. $\mathrm{O}$ instinto encontra seu alcance o instrumento apropriado: esse instrumento, que se fabrica e se conserta si mesmo, que apresenta, como todas as obras da natureza, uma infinita complexidade de detalhe e uma maravilhosa simplicidade de funcionamento, faz imediatamente, no momento desejado, sem dificuldade, com uma perfeição frequentemente admirável, o que é chamado a fazer. Em compensação, conserva uma estrutura praticamente invariável, uma vez que sua modificação não vai sem uma modificação de espécie. O instinto é, portanto, necessariamente especializado, não sendo mais que a utilização, para um objeto determinado, de um instrumento determinado. Pelo contrário, o instrumento fabricado inteligentemente é um instrumento imperfeito. Só é objeto ao custo de um esforço. É quase sempre de manejo difícil. Mas, como é feito de uma matéria inorganizada, pode assumir uma forma qualquer, servir para todo e qualquer uso, tirar o ser vivo, de toda nova dificuldade que surge e conferir-lhe um número ilimitado de poderes. Inferior a instrumento natural para a satisfação das necessidades imediatas, será tão mais vantajoso que aquele quanto menos urgente for a necessidade" (BERGSON, 2019, p.152-153). 
(BERGSON, 2011, p.35). E tal como no cinema "O quadro [...] constitui, portanto, um conjunto que possui um grande número de partes, isto é, de elementos que entram, por vez em subconjuntos" (DELEUZE, 2018, p.29).

O que nos leva a concluir parcialmente que cada corpo só será capaz de perceber - enquadrar -, imagens que estejam de uma maneira ou de outra, vinculadas ao imperativo de sua própria sobrevivência; àquilo que Bergson, mais especificamente, chamou de "apego à vida", e que permite aos corpos perceberem somente o que lhe importa. Caber-nos-ia perguntar agora, sobre qual seria o material de trabalho da percepção? De outro modo, o que percebe a percepção que percebe? Ou melhor dizendo, qual o plano dos enquadramentos da percepção?

\section{$1.2 \mathrm{O}$ movimento e o plano}

Ainda em Matéria e Memória, Bergson irá postular a existência de dois sistemas básicos de imagens: imagem-presença e imagem-representação. Respectivamente, o primeiro poderia ser concebido como um "turbilhão de luz", e diz respeito à multiplicidade qualitativa da matéria, constitutiva do real enquanto paisagem afectiva [não somente óptica, mas sonora, táctil, olfativa], composta de puras presenças intensivas em um nível genético-molecular, e, portanto, subrepresentativo, assignificante. Em termos mais precisos, tratarse-ia do plano de duração espiritual da matéria. É sobre estas imagens-duração, imagens-espírito, sobre este plano que atua a percepção.

Constituído de imagens imperceptíveis, que não foram percebidas ainda, e que de forma alguma divergem do movimento - aliás, poderíamos dizer que tais imagens são elas mesmas o movimento, a imagem-movimento, isto é, o fluir, o "marulho cósmico", o devir de desterritorialização e reterritorialização da Terra -, o primeiro sistema, corresponderia então ao próprio plano imanente da natureza, o mundo antes do homem, a imagem antes do olho. Palavras importantes foram ditas sobre este plano, no cinema de Deleuze: "O plano é o movimento considerado em seu duplo aspecto: translação das partes de um conjunto que se estende no espaço, mudança de um todo que se transforma na duração" (DELEUZE, 2018, p.40). Eis, de acordo com o bergsonismo

Ainda sobre a consonância entre plano, imagem e movimento da imanência, vaticina Deleuze: "Este conjunto infinito de todas as imagens, constitui uma espécie de plano de imanência. Neste plano a imagem não existe em si. Esse em-si da imagem é a matéria: não algo que estaria escondido atrás da matéria, mas, ao contrário, a identidade absoluta da imagem e do movimento. A identidade da imagem e do movimento que nos leva a concluir que a identidade da imagem-movimento e da matéria são idênticas” (DELEUZE, 2018, p.99). 
deleuzeano, "o universo como cinema em si, um metacinema" (DELEUZE, 2018, p.100).

Já o segundo sistema, tem especificamente a ver com as imagens já percebidas, derivadas dos enquadramentos, que os corpos enquanto centros de indeterminação deram conta de criar a partir do primeiro sistema. E se neste temos um fulgurante trânsito de imagens-movimento, percorrendo, colidindo e conectando-se aparentemente de forma aleatória umas com as outras por sobre o plano de natureza, aqui, no segundo sistema, encontramos imagens caracterizadas pelo recorte intencional por parte de um corpo vivo em relação ao todo aberto no qual está inserido.

Tal como em um écran, a consciência dos organismos vivos, ao ser atingida pela luminosidade material das imagens-presença que enxameiam o plano imanente da natureza, passa a selecionar através de quadros, somente aquelas que conforme já dissemos, lhe interessam do ponto de vista da ação. No caso dos organismos mais complexos e desenvolvidos, é aqui que o cérebro atuará no sentido de enviar os movimentos aos respectivos órgãos motores. O que em síntese, significa dizer que para Bergson, o segundo sistema de imagens será composto estritamente por imagens-representação - estas que povoam a memória e guiam cotidianamente as percepções e ações individuais ou coletivas dos sujeitos pelo mundo. Deste modo, "A coisa e a percepção da coisa são uma única e mesma coisa, uma única e mesma imagem, mas reportada a um ou ao outro dos dois sistemas de referência” (DELEUZE, 2018, p.106).

Importante é destacar neste momento o papel da memória que citamos anteriormente, e que através da qual os corpos irão perceber e agir sobre a realidade. Distinguimos dois tipos: a memória lembrança e a memória pura: uma chamada de atual, que teria a ver com a atualização presente dos movimentos sentidos, a outra, virtual, que denota o passado enquanto virtualidade em si. Nas palavras de Bergson, "Meu presente é aquilo que me interessa, o que vive para mim e, para dizer tudo, o que me impele à ação, enquanto meu passado é essencialmente impotente" (BERGSON, 2011, p.160). ${ }^{9}$ Assim, enquanto a

9 O que chamo de presente é minha atitude em face do futuro imediato, é minha ação iminente. De meu passado, apenas torna-se imagem, e, portanto, sensação, ao menos nascente, o que é capaz de colaborar com essa ação, de inserir-se nessa atitude, em uma palavra, de tornar-se útil; mas, tão logo se transforma em imagem, o passado deixa o estado de lembrança pura e se confunde com uma certa parte de meu presente. A lembrança atualizada em imagem difere assim profundamente dessa lembrança pura. A imagem é um estado presente, e só pode participar do passado através da lembrança da qual ela saiu. A lembrança, ao contrário, impotente enquanto permanece inútil, não se mistura com a sensação e não se vincula ao presente, sendo, portanto, inextensiva (BERGSON, 2011, p.164). 
memória lembrança seria condizente com as imagens que a inteligência acossada pelas demandas do presente atualiza tendo em vista movimentos reflexos, a lembrança pura, denotaria as impressões acumuladas involuntariamente ao longo da vida no inconsciente de um determinado corpo. ${ }^{10}$

Inevitável não retomarmos nossa reflexão acerca do hábito. Isso, pois acostumada que está a determinadas demandas, a percepção em seu imperativo de inteligência, tende a recorrer estritamente às imagenslembranças, diríamos aos "quadros de costume" que tem à mão, sem exigir muito de sua própria potência inconsciente. Ao passo que confrontada com a intempestividade de signos novos, se vê obrigada a vasculhar de forma mais detida a nuvem de virtuais que acompanha sua jornada pelo mundo. Em outras palavras, isso daria no mesmo que dizer que o hábito enquanto tendência do empreendimento orgânico dos corpos, atuaria pela desidratação de sua potência mnemônica. Preso no utilitarismo prático de seu cotidiano, acaba por lhes outorgar uma sensorialidade bastante reduzida do ponto de vista de toda sua capacidade. Não à toa, afirmando a liberdade contra toda pressa de uma época que começava a se acostumar com os dilemas da aceleração posta em curso pelo vigoroso processo de industrialização do entreguerras, Bergson dirá em tom quase que anedótico que é preciso esperar que o açúcar derreta (BERGSON, 2019). Ou seja, a despeito de perceber para agir, tal como são instados socialmente os corpos, se faz necessário perceber mais demoradamente, para sentir e agir diferente. E isso, somente a fissura do hábito é capaz de garantir.

Uma pausa no fluxo da exposição se faz necessária aqui. Isso, pois fazemos questão de reforçar essa reflexão acerca de como a percepção terá de ser atingida pela invasão de signos inéditos, a fim de que rompa com seu registro de costume, vindo a conquistar as condições de possibilidade para criação de pensamentos novos. É isto, aliás, que nos permitirá compreender os elementos religiosos explorados por Eisenstein em seus filmes, na tensão entre o velho e o novo, ainda que para Eisenstein esse "velho" não

10 Conforme explica Bergson: "A diferença, a nosso ver, é radical. Minhas sensações atuais são aquilo que ocupa porções determinadas da superfície de meu corpo; a lembrança pura, ao contrário, não diz respeito a nenhuma parte de meu corpo. Certamente ela engendrará sensações ao se materializar, mas nesse momento preciso deixará de ser lembrança para passar ao estado de coisa presente, atualmente vivida; e só lhe restituirei seu caráter de lembrança reportando-me à operação pela qual a evoquei, virtual, do fundo de meu passado. É justamente porque a terei tornada ativa que ela irá se tornar atual, isto é, sensação capaz de provocar movimento" (BERGSON, 2011, 163). 
corresponda ao sabido, ao dado, mas a estruturas potentes, desestabilizadoras, formalmente revolucionárias. A saber, conforme apresentaremos no decorrer deste artigo, foi muitas vezes através de materiais provenientes da religião que o cineasta russo, se viu capaz de fustigar o hábito, abrindo a consciência à novas realidades.

Porém, antes de prosseguirmos, vale ressaltar que até aqui nos detivemos na compreensão da epistemologia de Bergson, tal como apreendida por Deleuze. De modo específico, falamos dos modos pelos quais nossa inteligência lida com o plano de imanência das imagens-presença, produzindo, por sua vez, imagens-representação. $i$. A unidade mínima dos conjuntos fechados em relação com outros conjuntos do mesmo tipo, que corresponde aos enquadramentos; ii. Os enquadramentos, contíguos ao plano cinematográfico, que ultrapassando os conjuntos fechados em direção ao todo aberto, iii. Compõem, por sua vez, as representações respectivas às imagens-movimento. Agora, chegamos ao momento de especificarmos como que as imagensrepresentação serão organizadas sobre um plano-sequência, tornando-se imagem-movimento, ou filme, ou pensamento. Para tanto, discorreremos sobre a montagem cinematográfica, dando atenção especial à escola soviética de montagem, tal como apreendida por Deleuze.

\subsection{A mudança e a montagem}

A citação a seguir é de $A$ evolução criadora [1907], e apesar de sua extensão se faz indispensável:

Suponhamos que se queira reproduzir sobre uma tela uma cena animada, o desfile de um regimento, por exemplo. Haveria uma primeira maneira de proceder. Seria recortar figuras articuladas que representariam os soldados, imprimir a cada uma delas o movimento de marcha, movimento variável de indivíduo para indivíduo ainda que comum à espécie humana, e projetar o conjunto sobre a tela. Seria preciso empenhar nesse joguinho uma soma de trabalho formidável e só se obteria, aliás, um bem medíocre resultado: como reproduzir a flexibilidade e variedade da vida? Agora, há uma segunda maneira de proceder, bem mais tranquila ao mesmo tempo em que mais eficaz. Essa consiste em tomar uma série de instantâneos do regimento que passa e projetar esses instantâneos na tela, de modo que se substituam muito rapidamente uns aos outros. Assim faz o cinematógrafo. Com fotografias, cada uma das quais representa o regimento em uma atitude imóvel, reconstitui a mobilidade do regimento que passa. É verdade que, se nos deparássemos com as fotografias sozinhas, poderíamos olhá-las à vontade, não as veríamos ganharem animação: 
com a imobilidade, mesmo indefinidamente justaposta a si mesma, não faremos nunca o movimento. Para que as imagens ganhem animação, é preciso que haja movimento em algum lugar. O movimento realmente existe aqui, com efeito, está no aparelho. É porque a película cinematográfica se desenrola, levando sucessivamente as diversas fotografias da cena a darem seguimento umas às outras, que cada ator dessa cena reconquista sua mobilidade: ele enfileira todas as suas atitudes sucessivas no invisível movimento da película cinematográfica. O procedimento, portanto, consistiu em extrair de todos os movimentos próprios a todas as figuras um movimento impessoal, abstrato e simples, o movimento em geral, por assim dizer, em pô-lo no aparelho e em reconstituir a individualidade de cada movimento particular pela composição desse movimento anônimo com as atitudes pessoais. Tal é o artifício do cinematógrafo (BERGSON, 2019, p.330).

No parágrafo imediatamente seguinte, após expor o mecanismo do cinematógrafo, Bergson irá afirmar que é exatamente assim que atua nosso pensamento. Conforme atestam suas palavras, "Percepção, intelecção, linguagem geralmente procedem assim. Quer se trate de pensar o devir, quer de exprimi-lo, quer mesmo de percebê-lo, não fazemos realmente nada além de acionar uma espécie de cinematógrafo interior" (BERGSON, 2019, p.331). Desta feita, destacado do primeiro sistema de imagens - que é em si a dimensão interior da natureza, à sua duração -, nosso pensamento irá montar um "plano sequência" mental com os quadros criados, e que funcionará através da reprodução maquínica dos movimentos das imagens. "Resumiríamos então tudo o que precede dizendo que o mecanismo de nosso conhecimento usual é de natureza cinematográfica” (BERGSON, 2019, p.331).

Em cinema esta operação de articulação do todo em mudança exposto através do encadeamento maquínico das imagens-movimento, se chama montagem. Tal como explica Deleuze, "A montagem é essa operação que recai sobre as imagens-movimento para extrair delas o todo, a ideia, isto é a imagem do tempo. É uma imagem necessariamente indireta, pois é inferida das imagens-movimento e de seus nexos" (DELEUZE, 2018, p.55). Este tempo, representado indiretamente no cinema através das imagens-movimento, não corresponde a um tempo homogêneo, especializado ou cronológico, antes diz respeito à duração, que em si mesma desdobra-se como efeito do encadeamento das imagens-movimento tal como dispostos na montagem. Em Cinema 1, Deleuze listará quatro grandes escolas de montagem. A saber: $i$. A escola orgânica americana; ii. A escola dialética soviética; iii. A escola quantitativa francesa; $i v$. A escola expressionista alemã. Tendo em vista os 
limites deste artigo, e núcleo de nossos objetivos, iremos destacar apenas as duas primeiras.

Conforme explica Deleuze, foi D.W Griffith aquele que elevou o nível da montagem orgânica ao estatuto da narrativa. Através da inovação técnica do maquinário cinematográfico, foi ele quem extrapolou os registros imóveis feitos pela câmera parada, inserindo-os em um todo dinâmico e significativo. De tal forma que através dos novos tipos de enquadramento, planos, mise-en-scène dos atores e atrizes etc., fora ele a vanguarda daquilo que ficará conhecido como cinema narrativo, ou cinema clássico.

Sinteticamente falando, a montagem orgânica se dá quando todas as partes - personagens, coisas, acontecimentos etc.-, existem umas para as outras em função de um conflito dramático maior. Por isso, ela ocorre através da amarração entre todos os elementos do filme, dispostos em relação de interdependência. Nela tudo está relacionado com tudo, tal como em um organismo. É daí aliás, que Deleuze irá derivar seu nome escola orgânica de montagem. Nas palavras dele,

Griffith concebeu a composição das imagens-movimento como uma organização, um organismo, uma grande unidade orgânica. Foi essa sua descoberta. O organismo é antes de tudo uma unidade no diverso, isto é, um conjunto de partes diferenciadas: só há os homens e as mulheres, os ricos e os pobres, a cidade e o campo, o Norte e o Sul, os interiores e os exteriores" (DELEUZE, 2018, p.56).

Ainda de acordo com Deleuze, a escola griffthiana, ou americana, se apresenta em três formas, ou em três alternâncias rítmicas. A primeira delas, diz respeito a Montagem alternada e paralela. Aqui "suas partes são tomadas em conexões binárias [...], na qual a imagem de uma parte sucede à outra de acordo com um ritmo" (DELEUZE, 2018, p.56). Tal como exposto em Intolerância [1916], no qual contam-se quatro histórias situadas em momentos e espaços diferentes: narra-se paralelamente, através de alternações entre as cenas, a queda da Babilônia, a Paixão de Cristo, o extermínio dos huguenotes, e os dilemas vivenciados na América daquele período.

Junto do procedimento alternado, a escola orgânica americana, possui mais duas maneiras de montar. São elas as dimensões relativas e as ações convergentes. Por conta desta sua economia dos meios, um dos principais recursos aperfeiçoados por Griffith, será o close. É com este recurso, que ele irá explorar a relação entre os espaços paralelos, de tal modo a conjugar as 
visões dos conjuntos gerais com a miniaturização de conjuntos particulares. Tal como ocorre quando da tomada um plano americano, por exemplo, ser relacionada a visões de um primeiríssimo plano, onde estão sendo expostas as afecções de uma personagem... Ou seja, através destes recursos, uma situação $x$, operada em um espaço amplo, será ligada à uma situação $y$, desdobrada em outro espaço menor; produzindo com isso um efeito de relação e alternância. Vale destacar que é desta forma que Griffith irá manter vigente o suspense, no qual as ações das personagens tenderão a convergir no fim da narrativa

A compreensão destas três formas de alternância rítmica, se torna mais clara quando pensamos que agir e reagir é uma das principais características do cinema narrativo. Nesse sentido, trata-se sempre de conceber um conflito por detrás da história, que ameaça esfacelar a unidade do conjunto orgânico. E é assim, através do conflito das partes, que o todo se articula organicamente. Conforme descreve Deleuze, "De certas partes emanam ações que opõem o bom e o mau, mas de outras partes emanam ações convergentes que vêm socorrer o bom" (DELEUZE, 2018, p.57). Em O nascimento de uma nação (1915), tudo isso é muitíssimo evidente, e se revela por meio da vindita entre brancos e negros, sulistas e nortistas, escravocratas e abolicionistas etc.

Entrementes Serguei Eisenstein, será escolhido por Deleuze para capitanear suas reflexões acerca das mudanças instauradas pela segunda escola de montagem, a escola soviética dialética. Não precisamos dizer que com este cinema estamos a léguas de distância da escola americana. Contemporâneo da revolução de 1917, Eisenstein assumiu para si o chamado histórico de engenheiro metafísico de um novo humano e uma nova sociedade - falamos da sociedade sem classes do comunismo. Assim, diferente de Griffith, a quem ele desferirá severas críticas, o cineasta russo irá em busca de apropriar-se teoricamente das técnicas de montagem da escola americana, com vistas ao objetivo de ultrapassá-la. E serão basicamente dois os eixos centrais mobilizados por Eisenstein nesta tarefa. A saber, tal como discorreremos a seguir: $i$. A crítica à justaposição orgânica e contrarrevolucionária de Griffith; ii. A inserção da necessidade do elemento patético no organismo do filme.

Respectivamente Eisenstein acusará Griffith de pensar os conjuntos particulares enquanto partes exteriores umas às outras, ou seja, de maneira justaposta. Provenientes de uma origem distinta, essas partes serão pensadas e exibidas na montagem americana como dados autônomos, umas sem relação com as outras. Tal como explica Deleuze, "as partes diferenciadas do conjunto se dão por si mesmas, como fenômenos independentes. Como o toucinho, 
com sua alternância de gordo e magro: há pobres e ricos, bons e maus, brancos e negros etc." (DELEUZE, 2018, p.59). Oras, isso só será possível de ser concebido desta forma a despeito da consideração dos processos de gênese histórica que dão substancialidade material a estas partes; que com Griffith serão invariavelmente reduzidas a demandas individualizantes e acidentais, quer dizer, alienadas das dimensões estruturantes dos fenômenos sociais. Enfim, "Griffith ignora que os ricos e os pobres não são dados como fenômenos independentes, mas dependem de uma mesma causa gera, que é a exploração social" (DELEUZE, 2018, p.59).

Não é difícil de reconhecer as razões pelas quais a escola de montagem americana, foi taxada pelo cinema russo de burguesa. Afinal, ao negligenciar as dinâmicas sócio históricas que fundamentam os conflitos sociais, ela ainda assumia para si uma postura não científica, acrítica, por assim dizer. Nas palavras de Deleuze,

Griffith por ter uma concepção inteiramente empírica do organismo, sem lei de gênese nem de crescimento; por ter concebido a unidade de maneira inteiramente extrínseca, como unidade de congregação, reunião de partes justapostas, e não como unidade de produção, célula que produz suas próprias partes por divisão, diferenciação; é o fato de ter compreendido a oposição de maneira acidental, e não como a força motriz por meio da qual a unidade dividida refaz uma nova unidade por num outro nível. [...], Griffith não viu a natureza dialética do organismo e sua composição (DELEUZE, 2018, p.60).

E no lugar deste "empirismo cego" griffithiano, a escola soviética de montagem, sob sua figura de proa, reivindicará para si não mais a montagem por justaposição e sim uma economia das oposições. Por conseguinte, não se trata mais de pensar em termos de uma reconciliação dos contrários dentro de uma mesma unidade orgânica, mas uma unidade fendida em polos opostos; que através da lógica do uno que divide em dois, atribui o caráter dialético ao cinema russo. Assim, os dramas burgueses americanos, darão lugar ao drama proletário soviético, donde uma lei de gênese regerá todo processo de composição narrativa, isto é, a luta de classes. E é através do movimento gradativo de progressão dialética - do um que se divide em dois em uma espiral ascendente e, que se repetirá ao longo de todos estes filmes -, que Eisenstein inventará então um filme novo para uma sociedade nova.

Porém, ainda não mencionamos outro componente fundamental desta montagem, sem o qual ela não chegaria a termo. Falamos dos "saltos 
dialéticos", dos momentos de ruptura, que no decorrer ascendente da espiral em processo dilatação, termina por culminar na explosão de uma nova realidade, uma nova consciência. E aqui, passamos imediatamente à segunda objeção de Eisenstein à escola americana, a saber, o caráter patético da montagem soviética que deverá somar-se à disposição orgânico-narrativa dos filmes.

Para os soviéticos, não basta que os espectadores se sintam envolvidos pela trama das personagens, não é suficiente que se identifiquem com seus dilemas e saídas moralizantes - tudo isso, ainda é muito burguês. Antes, se faz necessário arrancá-los de suas zonas de conforto, através "murros no cérebro", verdadeiras descargas elétricas, que terão por função perturbar sua estrutura sensório-motora, lhes causando empatia e simpatia pela causa revolucionária. Portanto, com eles, não haverá "apenas a unidade orgânica dos opostos, mas a passagem patética do oposto a seu contrário. Não há apenas liame orgânico entre dois instantes, mas o salto patético em que o segundo instante adquire uma nova potência” (DELEUZE, 2018, p.62).

A respeito desta elevação da imagem a uma potência outra, que confrontará o público com o elemento pático, isto é, chocante, intolerável, odiento, e que por sua vez, será responsável por dirigir o drama a dar mais uma volta na espiral - o exato momento de clivagem quando o um que se divide em dois, e que por fim culmina em uma realidade e consciência diferentes -, citamos por exemplo, a cena dos vermes na carne podre servida aos marinheiros das tropas czaristas do exército russo, e também o surgimento da cor vermelha, presente na bandeira hasteada após uma vitória destes mesmos marinheiros ao final do terceiro ato, em Encouraço Potemkin [1926]. Ou também, a os animais introduzidos por Eisenstein em A greve [1925] - de modo breve, nos referimos a sobreposição de imagens dos homens e bichos, que na cena com os arquivos do distrito fabril no início do filme, deflagra uma espécie de devir monstro nos trabalhadores; ou a cena dos gatos mortos pendurados pelo pescoço na cena que abre o capítulo cinco, "Provocação para o massacre".

Intrigante é ponderar o fato de que conforme mostraremos a seguir, Eisenstein irá lançar mão de uma série de elementos religiosos no momento de compor seus filmes. O que, por consequência nos leva a cogitar a possibilidade de que para ele, a religião se constituía enquanto fonte de inspiração privilegiada. Se considerarmos tudo o que dissemos até aqui, diremos que tudo se passa, como se o diretor russo soubesse a potência da religião no que tange ao objetivo de fazer pensar. De outro modo, é como se 


\section{Giovanni Felipe Catenaci}

Paulo Augusto de Sonza Nogueira

no momento de preparação de seus golpes, a religião se fizesse indispensável a Eisenstein. Mas como os elementos religiosos serão desenvolvidos pelo cineasta russo? Em outras palavras, como esse cinema [religioso] faz pensar? É o que buscaremos a pensar em seguir...

\section{Eisenstein e o pensamento sensorial: estruturas arcaico- religiosas a serviço da revolução}

$\mathrm{Na}$ segunda parte de nosso artigo apresentaremos aspectos da reflexão de Eisenstein sobre o cinema e sua relação com as estruturas arcaicas de pensamento. Trata-se de um tema cada vez mais presente em sua obra nos anos 30, tendo ganhado mais atenção a partir de sua viagem ao México, onde fez as filmagens para o filme Que Viva México! O trabalho em torno a esse filme marcou um divisor de águas em sua teoria do cinema. Eisenstein ficou impressionado com a cultura mexicana, com a presença de elementos ancestrais, de um passado distante, mas ainda presentes na organização da vida daquela sociedade. Na verdade, Eisenstein sempre estivera consciente do aspecto regressivo da arte, de seu fundamento em estruturas antropológicas primitivas, mas ele sempre resistira a essas estruturas por relacioná-las com a linguagem mítica, que por ele ainda era considerada perigosa, afinal, era em formas míticas que se fundamentavam as ideologias dos regimes nazista e stalinista. Que a arte tivesse esse elemento regressivo era aparentemente incompatível com sua função revolucionária, vanguardista, com seu papel na moldagem de uma nova sociedade. No entanto, nos seus escritos a partir da década de 30 e, principalmente, nas obras que deixou incompletas quando do seu falecimento em 1948, como Method e Grundproblem, Eisenstein passou a se ocupar com esse aspecto ambíguo do cinema: sua estruturação em formas arcaicas e primitivas de pensamento e, ao mesmo tempo, sua função progressiva e revolucionária. Ele expressa isso em sua fórmula paradigmática: “... não há forma na arte sem tendência em direção à regressão, da mesma maneira que não há conteúdo sem uma tendência em direção ao progresso" (apud IVANOV, P. 181). Eisenstein também apresenta essa tensão de outra forma:

A dialética de uma obra de arte é constituída de uma "unidade dupla" muito curiosa. A eficácia de uma obra de arte é construída sobre o fato de que ocorre nela um processo duplo: uma impetuosa ascensão progressiva ao longo das linhas dos mais elevados degraus explícitos da conscientização e uma simultânea penetração através da estrutura das formas nas camadas do mais profundo pensamento sensorial. A separação polar dessas duas linhas 
de fluxo cria a incrível tensão da unidade da forma e conteúdo característica das verdadeiras obras de arte. Fora disto não existem verdadeiras obras de arte (EISENSTEIN, 2002, p.135-136)

Eisenstein era um intelectual sofisticado e polivalente, que não só estava bem-informado sobre pesquisas na área da psicologia, antropologia etc., e familiarizado com as teorias de autores como Frazer, Levy-Bruhl e Freud, entre muitos outros. Ele também tinha amizade pessoal e colaborava diretamente com pesquisadores como Luria, Vygotsky e Marr (BULGAKOWA, 2014; VASSILIEVA, 2019). Essas leituras e relações lhe permitiam ter um olhar da história da arte a partir de suas estruturas antropológicas elementares. Inspirado por Levy-Bruhl e estudioso do que este chamava de "pensamento pré-lógico", Eisenstein explorou esses elementos na formação da arte, mas preferiu chamar essas estruturas arcaicas de "pensamento sensorial", ou seja, aquelas provenientes dos primeiros estágios do desenvolvimento humano e que continuam a operar na psique do homem contemporâneo no nível inconsciente. De fato, Eisenstein argumentava que a origem dessas estruturas de percepção do mundo podia ser encontrada nas formas mais elementares de vida orgânica. Trata-se de uma surpreendente antecipação de conexões de modos de existência e suas formas de percepção entre humanos e não-humanos, que apenas recentemente estão sendo retomadas nas ciências humanas. $\mathrm{O}$ apelo da arte nesse aspecto primitivo, sensorial, se dá no seu enraizamento nessas estruturas primitivas da vida biológica, caracterizadas por conectividade, não-diferenciação, marcadas por formas básicas como os gestos, os ritmos, e a sinestesia, ou seja, a capacidade de perceber diferentes sensações ao mesmo tempo. Tudo isso transforma o cinema na "mais moderna forma da síntese orgânica de arte". (EISENSTEIN, 2013, p.194)

É em relação à passagem do sensorial para o lógico que Eisenstein entende estar fundado o trauma que marca a cultura humana, o que ele chamava de Grundproblem, o "problema básico". Segundo Oksana Bulgakowa,

"Eisenstein sugere que durante a percepção extática da obra, a arte ativa e provoca no observador uma mudança para o pensamento sensorial pré-lógico, que rompe com a consciência racional como um chacoalhão, como o faz o inconsciente no modelo de Freud. Assim a estrutura da obra de arte é percebida como uma consciência multicamadas e a totalidade da diversidade de formas é vista como uma cadeia sem fim de variantes que se originam do trauma básico que a consciência experimentou no curso da evolução, na transição do pensamento pré-lógico para o lógico”. (BULGAKOWA, 2013, p.212) 
Este conflito de base é análogo ao conflito social, como mostrado por Marx, ou ao conflito psíquico, como estudado em Freud. Na arte este trauma é atualizado e vivido em formas de catarse, de êxtase, de processos em que a indiferenciação é experimentada, como na alteração da consciência por uso de álcool, drogas, estados esquizofrênicos ou no orgasmo sexual. (BULGAKOWA, 2014, p. 425)

Essas ideias de Eisenstein nos parecem muito pertinentes para a discussão das relações entre religião e cinema por dois motivos. Primeiro, porque nos oferece uma alternativa às abordagens que privilegiam relações de paralelismo ou de correlação, de que religião e cinema estão em relação uma vez que os temas da primeira são abordados no segundo, privilegiando assim relações temáticas. Se, no entanto, cinema e religião remetem às mesmas estruturas antropológicas primitivas, se são constituídas das formas elementares de percepção do mundo, suas relações são mais profundas. Desta forma, o "cinematógrafo interior" ganha dimensões antropológicas, incidindo sobre nossos modos de imaginação, como nos devaneios, nos sonhos e nas projeções, que E. Morin chama de antropocosmogônicos (2014). O segundo motivo se refere ao fato de que cinema e religião nos permitem revisitar o fascinante e proscrito tema do animismo, das conexões entre modos de existência, tal como têm sido propostos recentemente pelos estudos do New Animism e da virada ontológica ${ }^{11}$. No pensamento animista há atribuição de vida (anima), agência, a objetos, espaços, imagens, plantas, animais e, inclusive, aos mortos. As coisas e entidades não são só dotadas de sentido, mas também de poder de agência. Animismo era a origem da religião segundo E. B. Tylor (2016). Infelizmente seus pressupostos evolucionistas o fizeram entender estarem essas relações enterradas num passado distante ou vivas em povos primitivos de lugares exóticos. Entre os "civilizados" relações animistas só podiam ser encontradas em resquícios culturais ("survivals", em sua terminologia). Na perspectiva de Eisenstein, no entanto, esses elementos primitivos e hiperconectivos estão operantes nos seres humanos contemporâneos, sendo a arte um desses espaços privilegiados. No cinema, portanto, uma paisagem, um objeto, um rosto em close-up, ganham não só sentido, como também potência de agência. As relações entre animais

\footnotetext{
11 A discussão em torno do animismo e das possibilidades de renovação do conceito é intensa e multifacetada. Para uma perspectiva sobre o debate ver KOHN, Eduardo. Anthropology of Ontologies. The Annual Review of Anthropology 44, 2015, p. 311-327 e LAACK, Isabel. The New Animist and Its Challenges to the Study of Religion, Method and Theory in the Study of Religion 32, 2020, p. 115-147.
} 
e humanos são marcadas por relações de substituição, e entre humanos e objetos por deslizamentos metonímicos. Nessa segunda perspectiva, tanto a religião quanto o cinema oferecem possibilidades de criar presenças e relações, identificações profundas entre atores e personagens, e do público com estes, além de identificações com espaços e objetos. Estas relações são reforçadas por processos sinestésicos, em que na imagem se experimenta textura, sabor, temperatura etc. Ou seja, tanto cinema quanto religião se encontram nessas embodied experiences - que em português teríamos que chamar, provocativamente, de "experiências incorporadas", altamente conectivas, produtoras tanto de polissemia, de criação de sentido, quando de espaços potenciais de relações e de presença.

Ilustraremos esses aspectos de pensamento sensorial, de estruturação da imagem do cinema nas estruturas arcaicas, em cenas escolhidas de três filmes de Eisenstein. Em dois deles incorreremos em certo anacronismo, uma vez que os filmes são anteriores às reflexões maduras do cineasta soviético em torno ao pensamento sensorial. Entendemos, no entanto, que a montagem cinematográfica de Eisenstein já obedecia, de alguma forma, aos princípios que veio elaborar e desenvolver e explicitar posteriormente. Ilustraremos alguns desses eixos em A Greve (1924) e no Encouraçado Potemkin (1925). Por fim, analisaremos apenas uma parte de Que Viva Mexico! (1931), intitulada "Dia de los Muertos". Sem qualquer pretensão de exaustão, nosso objetivo é mostrar eixos imagéticos do pensamento sensorial em ação, com o objetivo de identificar neles estruturas antropológicas fundamentais. Insistimos que as estruturas religiosas operam em seu interior, não em paralelo, nem representando outro âmbito, mas sendo a mesma coisa. A separação do religioso nessas imagens só pode ser feita por motivos didáticos. Sucederemos se pudermos apontar para relações entre cinema e religião confluídas nessas imagens fundamentais e de mostrar seu poder de, a partir de imagens elementares e arcaicas, sacudir o ser humano em direção a uma inquietação, a um movimento, quem sabe em algum nível de consciência e de ação revolucionários.

\section{1 Homens e máquinas, homens e animais e A Greve}

O filme A Greve ${ }^{12}$ inicia com planos de imagens de instalações industriais nas quais seres humanos são enquadrados entre máquinas, roldanas, polias, estruturas de ferro (como torres). O primeiro ser humano mostrado

12 Usamos a edição do filme disponível em https://www.youtube.com/watch?v=hG yM7We0C8, acessado em 12/07/2012. 
Paulo Augusto de Souza Nogueira

de forma plena, colossal, num riso grotesco, é o proprietário da fábrica, com sua gargalhada zombeteira e triunfante (imagem 0). Em seguida, os trabalhadores, em agitação revolucionária, só podem ser visualizados entre instalações industriais e máquinas (imagem 1 e 2). Seus corpos em agitação, gesticulando, conversando, se fundem com o movimento das roldanas e engrenagens. Prevalece nessa tensão dialética entre homens e máquinas o ritmo, marcado pela montagem, alienante no começo, mas revolucionário depois, conduzindo à síntese, quando os trabalhadores decidem cruzar os braços em greve, ao final da primeira parte. ${ }^{13}$ Nesse momento a imagem sobreposta das máquinas desvanece, ficando em evidência apenas os corpos dos trabalhadores com os braços cruzados (imagem 3). A tomada de decisão em favor da greve marca o momento de visualizar a humanidade plena desses operários (imagem 4).

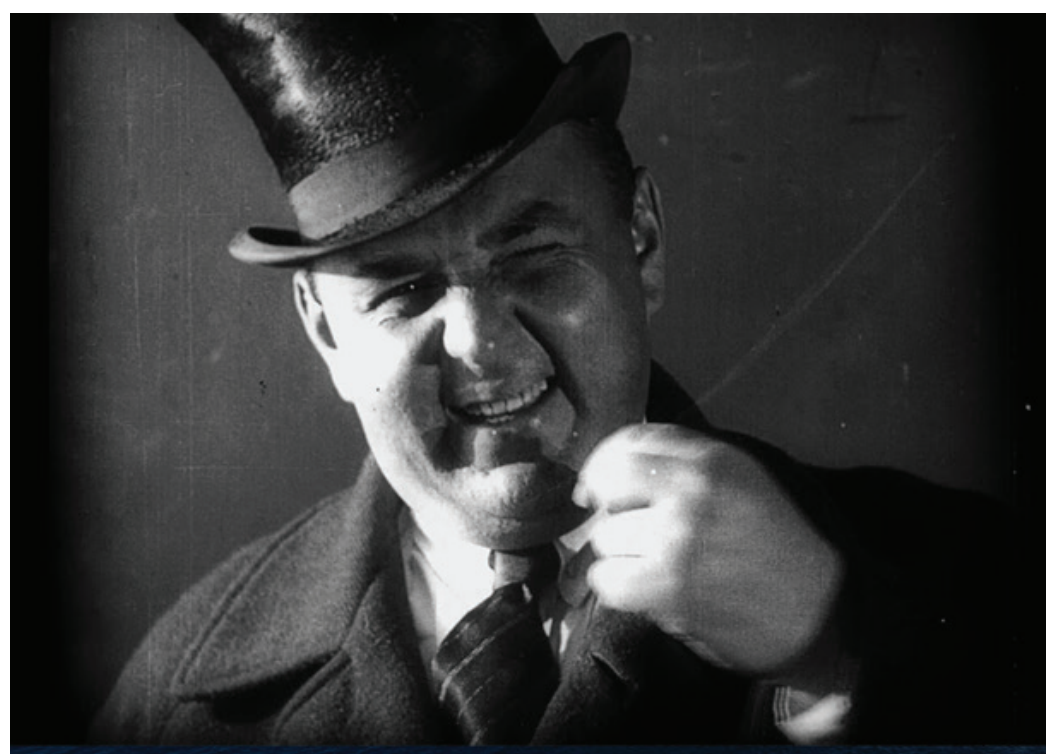

Imagem 0 - Observando a fábrica

13 Sobre essa tomada de decisão revolucionária no cinema de Eisenstein, Deleuze dirá que "a consciência é o patético, a passagem da Natureza ao homem, e a qualidade que nasce da passagem efetivada. É simultaneamente a tomada de consciência, é a consciência atingida, a consciência revolucionária atingida pelo menos até ponto. [...]: é o salto orgânico que produz uma consciência externa da Natureza e de sua evolução, mas também uma consciência interna da sociedade e de sua história, de um momento ao outro do organismo social" (DELEUZE, 2018, p.64). 


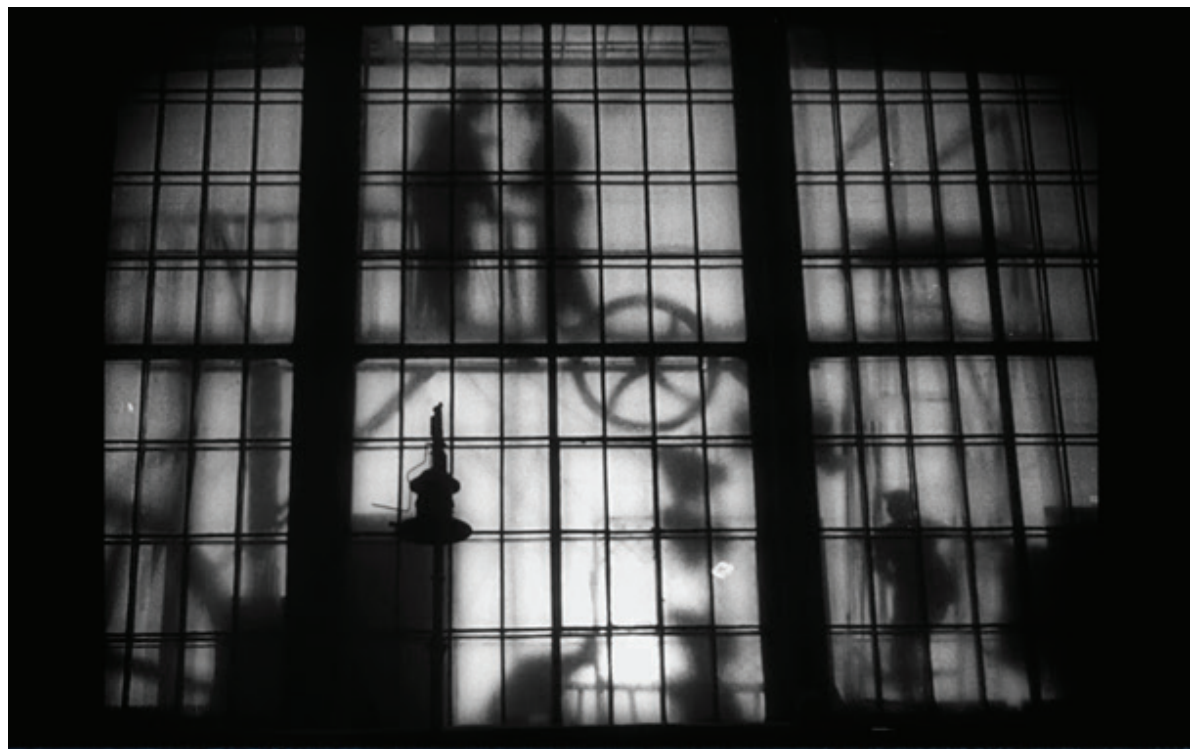

\section{Imagem 1 - Conspirando}

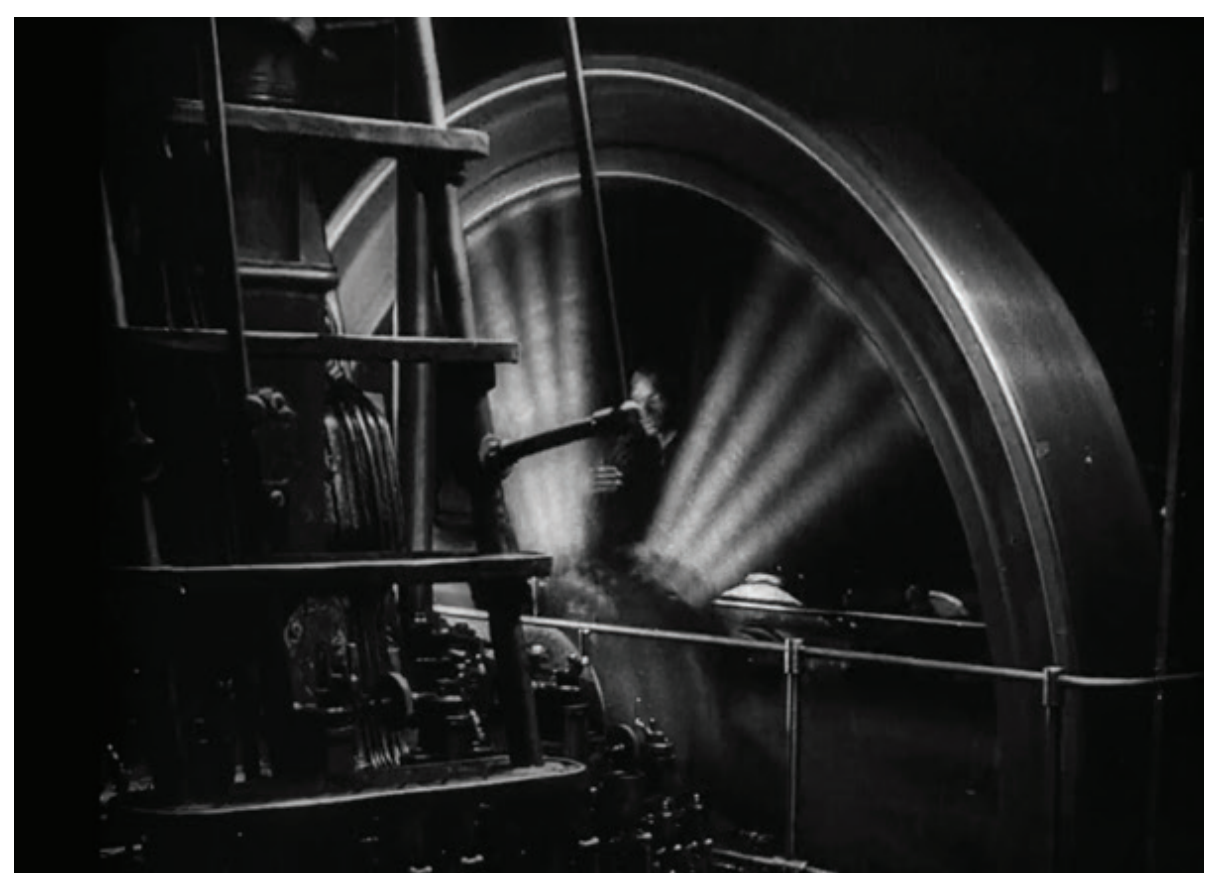

Imagem 2 - Entre máquinas 


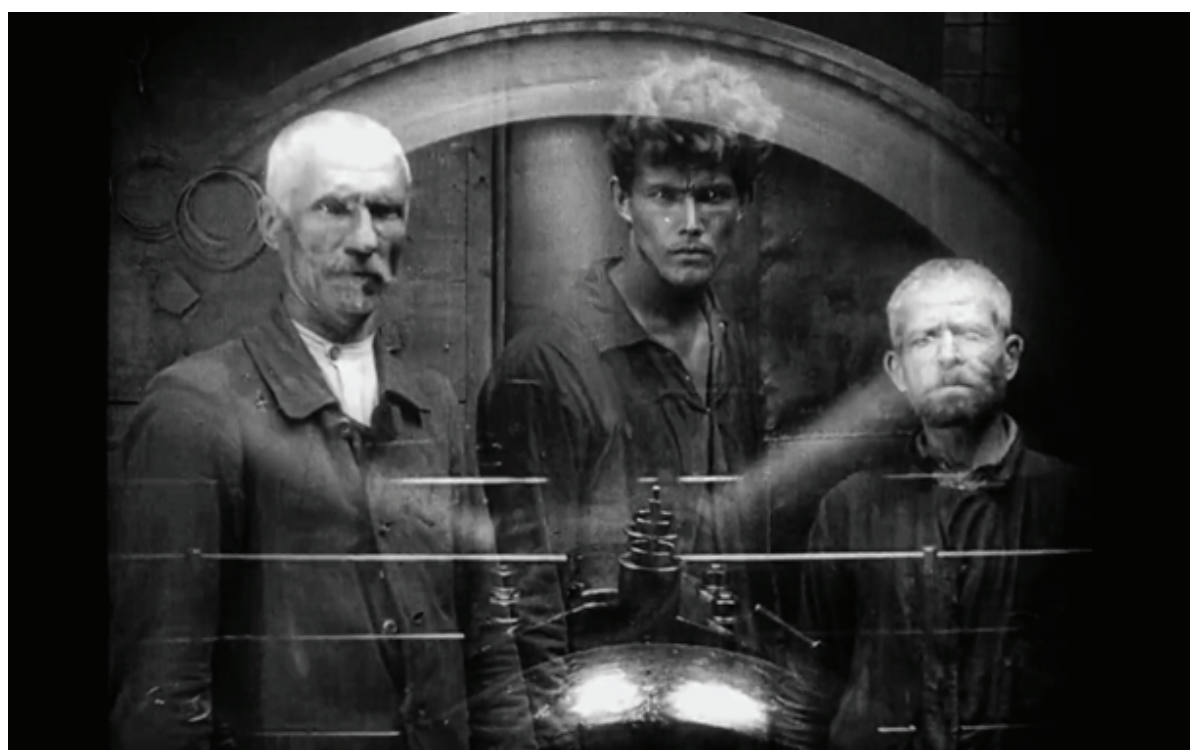

Imagem 3 - Saindo das engrenagens

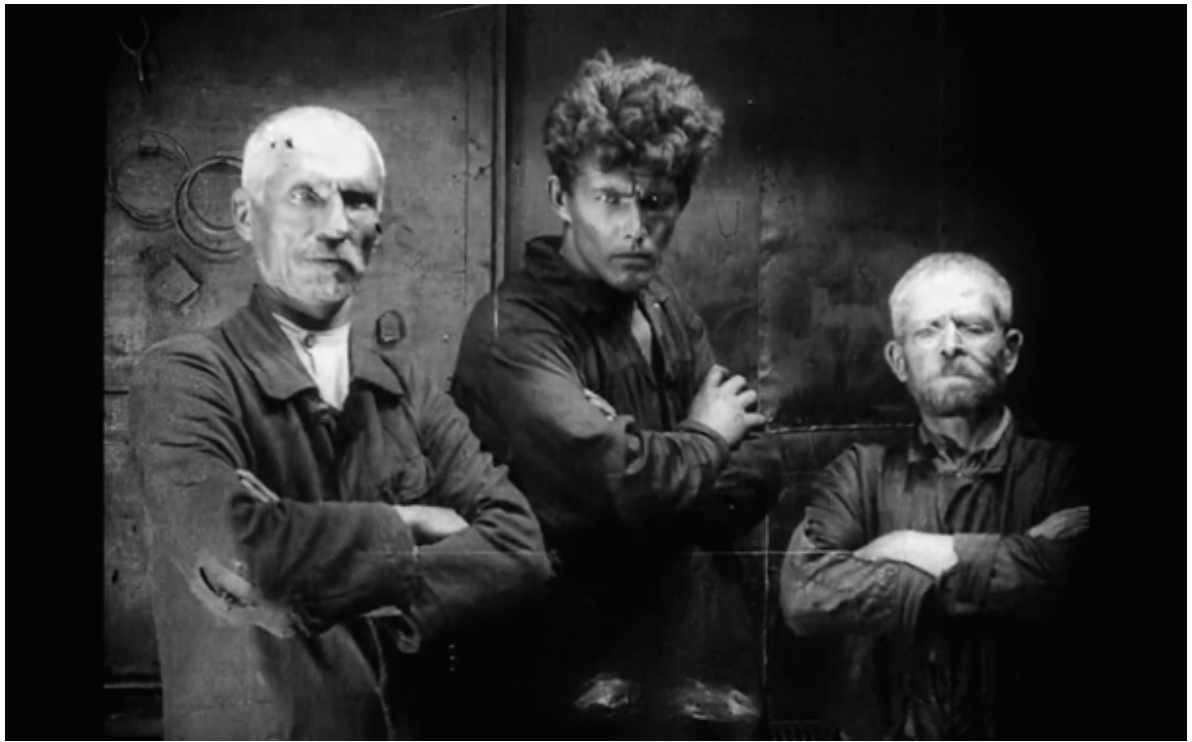

Imagem 4 - Paralização 
Um segundo campo imagético que complementa o da tensão dialética entre máquinas e humanos é o das relações entre animais e humanos. Quando a polícia, por encomenda do proprietário da fábrica, arregimenta espiões para mapear as atividades grevistas dos trabalhadores, eles são apresentados em sequência, em imagens sucessivas de sobreposições de rostos humanos por animais. Um espião tem o rosto transformado (sobreposto) por uma coruja, outro por uma raposa, outro um macaco (imagem 5 e 6). Essas metamorfoses, tão frequentes na mitologia e no folclore, são muito significativas nessa cena. Nas tensões dialéticas apresentadas pelo filme os trabalhadores lutam contra forças na natureza e forças do mundo das máquinas industriais. Eles só encontram descanso e paz quando no início da greve estão em suas casas entre crianças e animais domésticos, ou nos campos, quando dançam e reforçam seus laços de solidariedade. Mas as tensões são retomadas no filme por ação de criminosos arregimentados pelos contrarrevolucionários e quando entram em cena policiais montados. Os cavalos da polícia assumem um papel bestial demoníaco, servindo para perseguir os grevistas, mesmo em escadarias, em ascensões improváveis, quando os cavaleiros sobem até o terceiro e quarto andar dos prédios de moradias habitados pelos operários para dali lançá-los abaixo. No mais elevado desses espaços, os cavaleiros arremessam crianças (imagem 7).

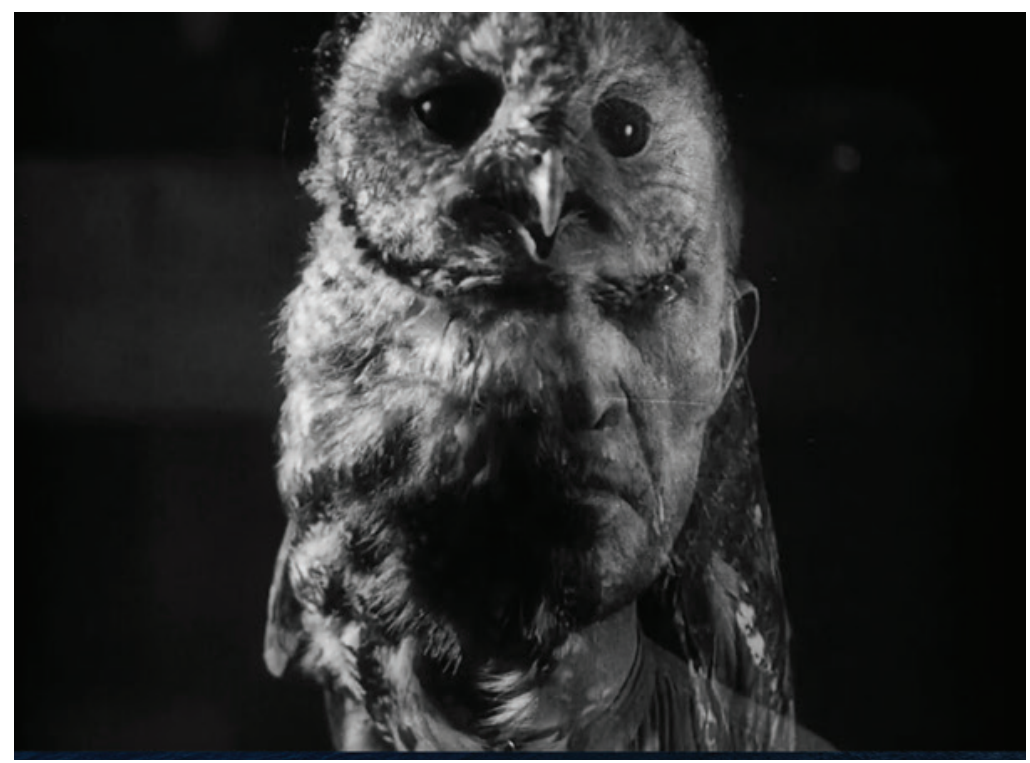

Imagem 5 - Metamorfose 


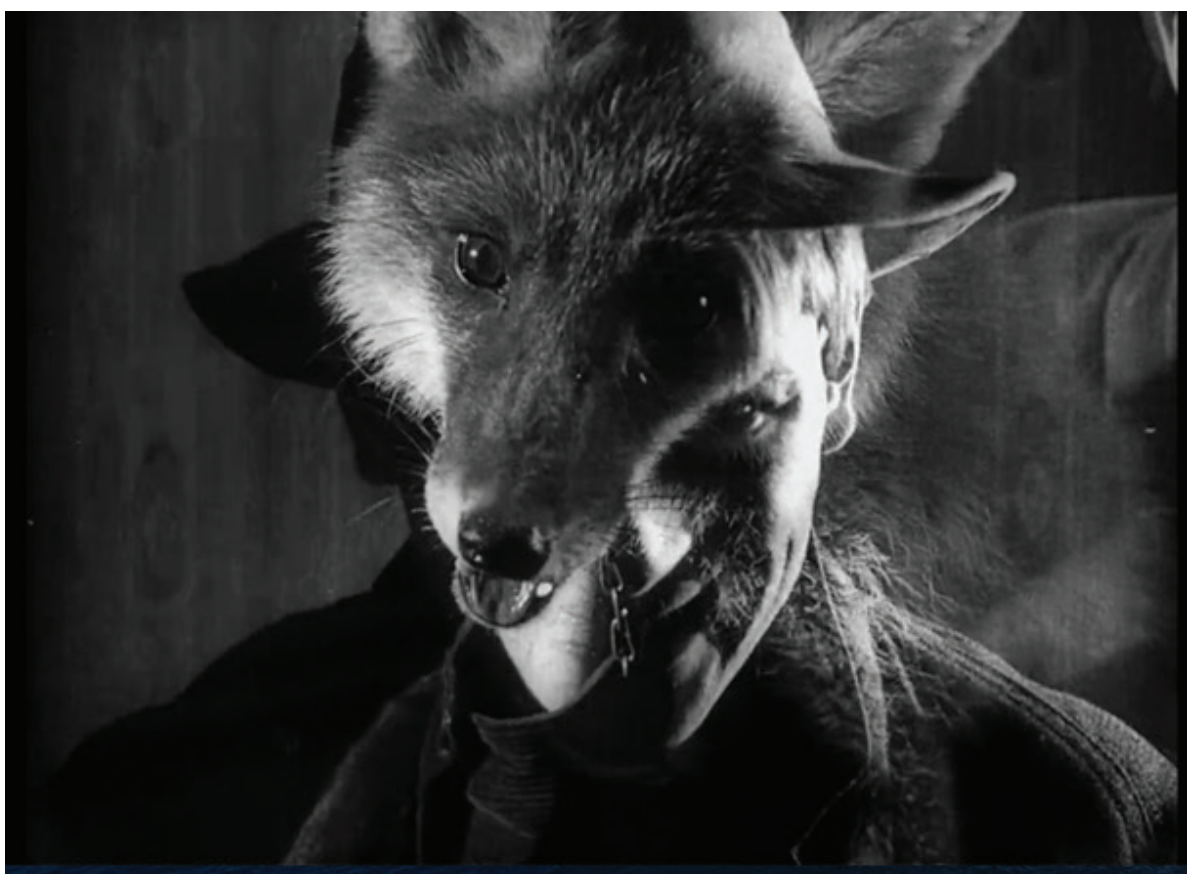

Imagem 6 - Metamorfose 2

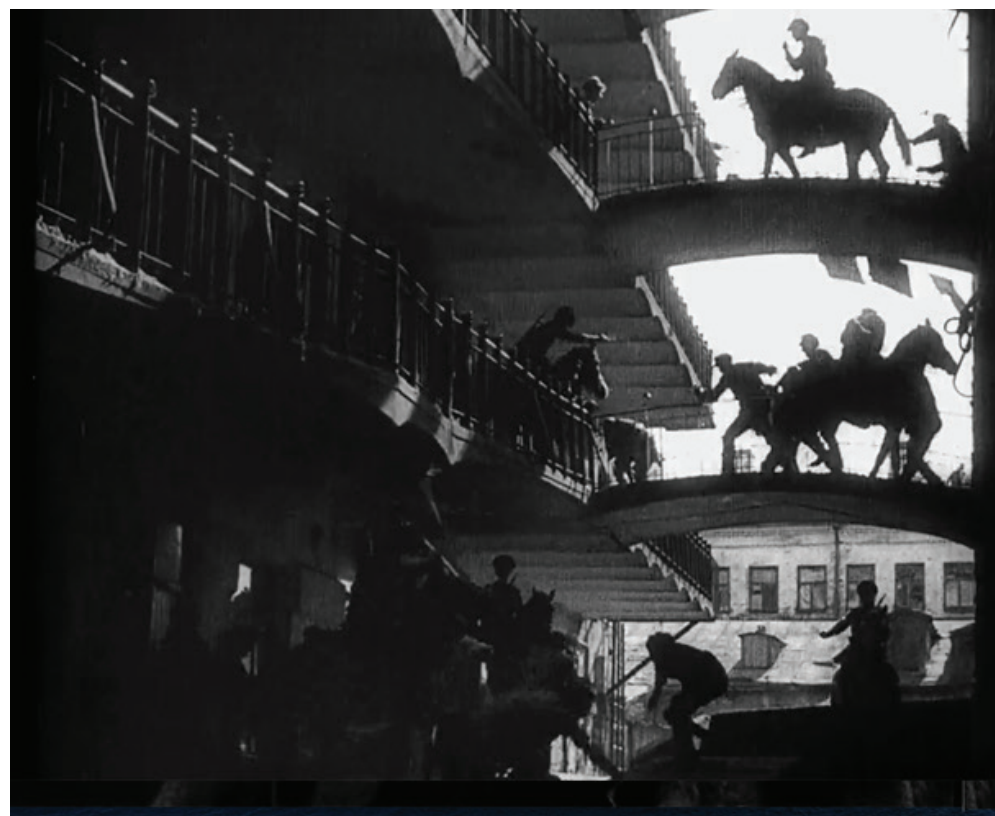

Imagem 7 - Monstros 
A última cena do filme, chamada sugestivamente de "carnage", oferece um desfecho poderoso no qual a montagem opõe dialeticamente trabalhadores amontoados, correndo para cima e para baixo para escapar dos soldados armados com fuzis, com a cena do abate de um boi. Primeiro temos uma imagem que mostra grupos correndo, substituídos metonimicamente por mãos suplicantes em movimento, num pars pro toto que amplifica a presença dos trabalhadores suplicantes por misericórdia. As cenas que seguem são alternadas na montagem dialética, em ritmo frenético e dramático, em fusão entre humanos e animais. O destino do boi sacrificado em primeiro plano antecipa o dos trabalhadores. Quando jorra sangue do boi, caem por terra trabalhadores baleados, numa confluência de imagens paralelas (imagem 8 e 9). Após o jogo entre esse um que representa todos, animal e grupo de operários grevistas, é mostrado um close-up dos olhos de um homem de rosto franzido, tenso, que pronuncia a frase final: "lembrem-se!".

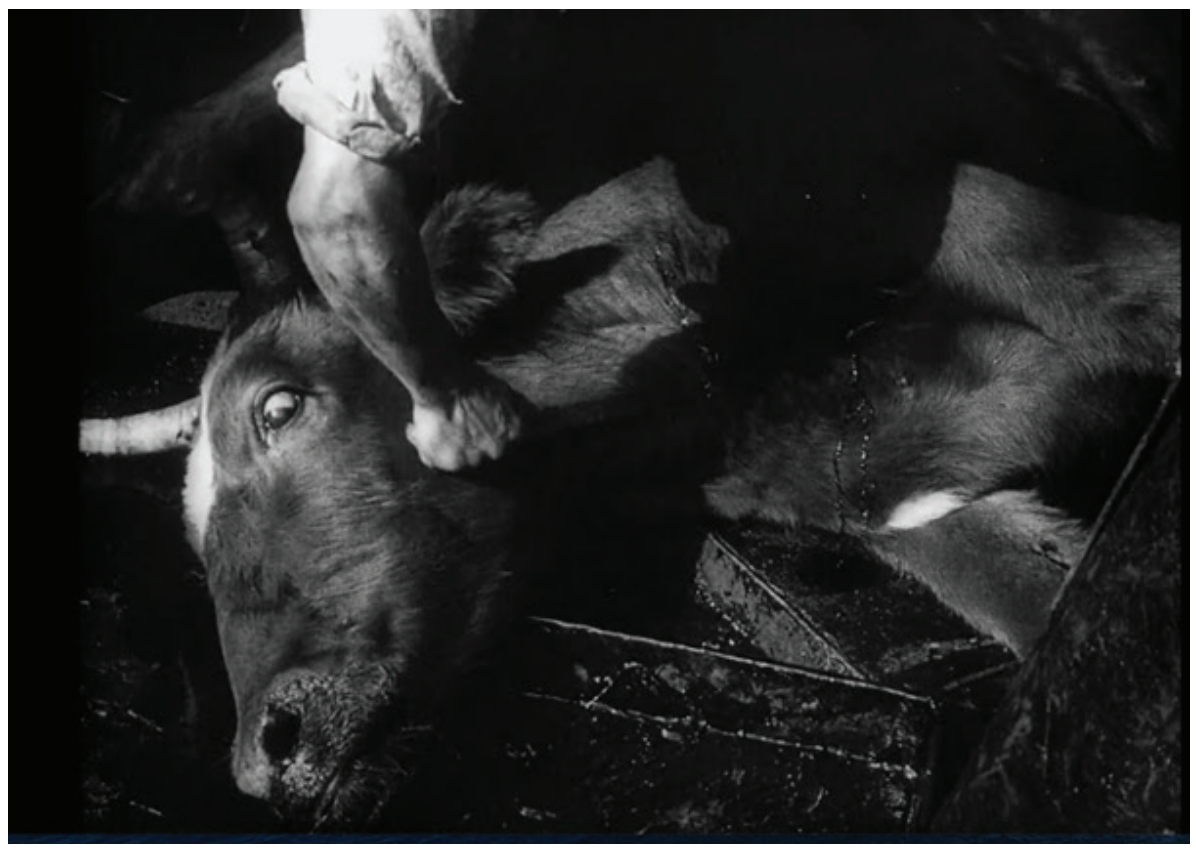

Imagem 8 - Sacrifício 


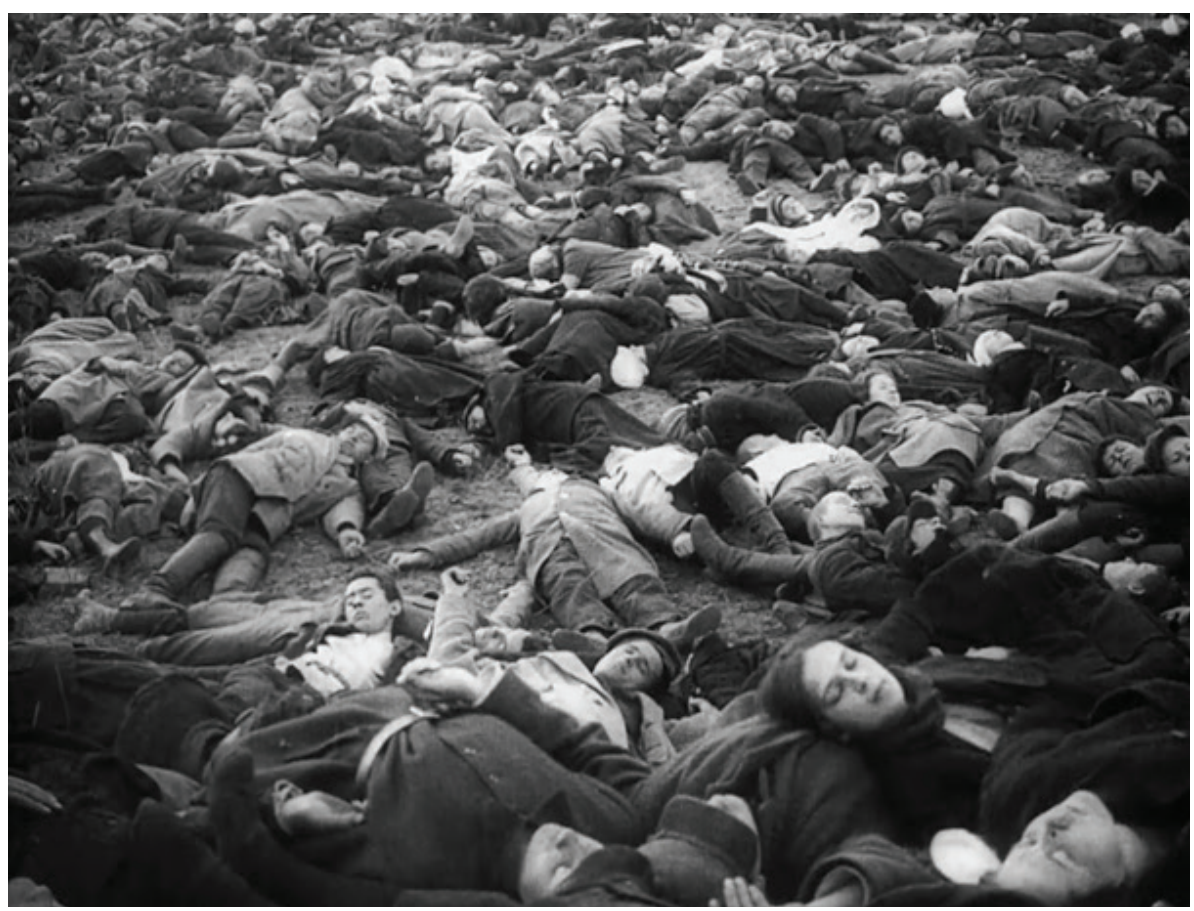

Imagem 9 - As vítimas

Estas fusões e alternâncias dialéticas de imagens promovidas na montagem promovem pensamento revolucionário, tensão entre proprietário que ocupa o plano todo, que ri debochadamente, em oposição a trabalhadores que se organizam em conversas escondidas entre máquinas e instalações, sendo muitas vezes quase invisíveis entre elas. A relação com os animais é ambígua. Se eles estão presentes nas casas dos trabalhadores em greve, nos quintais, entre crianças, eles também predominam em fusões de inimigos ardilosos como os espiões ou em cavalos demoníacos que sobem agilmente em seu encalço em seus apartamentos ou perseguindo-os pelos campos. Por fim a simbiose se dá entre o boi abatido num matadouro, olhos esbugalhados, sangue que jorra, e os trabalhadores mortos no campo após fuga desesperada. E o close nos olhos desesperados de um homem que diz: "lembrem-se". A força revolucionária do filme repousa certamente na montagem, na contraposição dialética de planos que acirram tensão e movimento. Mas o filme não atingiria o mesmo êxtase se não lidasse com essas fusões e oposições fundamentais, construídas com essas imagens que estruturam a 
experiência do corpo no pensamento mito-poético, de um corpo em tensão com as máquinas e com o mundo bestial, ambíguo, numa violência que remete aos sacrifícios ancestrais.

\section{2 Ascensões e descensos, repressão e revolução no Encouraçado}

O Encouraçado Potemkin ${ }^{14}$ é umas das obras mais importantes de Eisenstein. Seu enredo é baseado em fatos ocorridos no porto de Edessa, em 1095, quando a população do navio se rebelou contra seus oficiais superiores. A narrativa se inicia com a revolta de marinheiros do encouraçado que se recusam a comer carne podre que seria servida em suas refeições. Os oficiais decidem pela execução dos marinheiros que recusaram a sopa, o que provocou uma rebelião com a tomada de posse do navio. Nessa rebelião é morto o líder dos marinheiros, Vakulinchuk. Ao ser colocado o corpo do líder da revolta numa tenda na costa, em Edessa, a população acorre para velá-lo, se identificando com seu destino. Vakulinchuk torna-se uma espécie de Cristo. Por fim, a população de Edessa se torna solidária com os tripulantes rebeldes, levando-lhes alimento e saudando a revolução. O contraste é evidente: se dos superiores os marinheiros ganharam carne estragada, violência e morte, da população, irmanada no ideal revolucionário, eles recebem alimento com fartura. Mas o poder não podia tolerar aquela festa solidária popular. Os cossacos - temida guarda czarista - desce marchando para cima do povo na escadaria de Edessa, atirando e matando todos os que estavam em seu caminho. O encouraçado revida bombardeando o palácio do governo. Por fim, o Encouraçado deverá se encontrar com a esquadra enviada pelo governo, cruzando a sua rota. Os marinheiros vivem uma noite de tensão e medo, pois teriam que enfrentar as forças governistas que estavam em muito maior número. Eles se preparam, carregam os canhões, se despedem uns dos outros. Quando, no entanto, se aproxima a esquadra, em alcance de tiro, um dos marinheiros tem a iniciativa de fazer sinais com as bandeiras do navio com o apelo: “irmãos!”. Após segundos de tensão os marinheiros da esquadra também respondem como a mesma mensagem. Festa e celebração tomam conta dos marinheiros de todos os navios.

14 Disponível em https://www.youtube.com/watch?v=3U_SsH9Rl2E, acessado em 03/07/2021. 
Este filme claramente está voltado para o futuro, para pautas revolucionárias, para a transformação da sociedade. No entanto, segundo a proposta de Eisenstein, para que possa impactar como arte ele precisa remeter a elementos do pensamento sensorial, para estruturas primitivas. Já nas primeiras cenas a narrativa é tomada por elementos estruturantes arcaicos. Um deles é a verticalidade das cenas, expressa nos motivos de descenso e da ascensão. Na cena de abertura o oficial que vigia o sono dos marinheiros desce uma escada até o compartimento escuto e apertado onde eles dormem em redes sobrepostas. Esse espaço, fundo, escuro, claustrofóbico, de redes caoticamente sobrepostas, é o lugar desde onde a revolução é gestada (imagem 10). Na cena seguinte o oficial que vem acompanhar o questionamento dos marinheiros que se recusam a comer a carne estragada, desce de um compartimento superior. Ele é filmado de cima para baixo, ou em ângulo inverso, da perspectiva dos marinheiros, de baixo para cima. Há uma verticalização dessas tomadas (imagem 11 e 12). Também há ênfase na hierarquia com o close-up, tanto do médico no navio como do oficial. No primeiro caso, o close-up é frontal, quando ele fala movendo os braços, afirmando (ou gritando?) que a carne está boa. No caso do oficial, o rosto é focado de baixo para cima. Por fim, há uma troca de olhares cúmplice entre os dois, que se retiram do local da discussão. Essa forma de estruturar o filme verticalmente se repete nas cenas do povo que desce por muitas escadas e caminhos até o cais, onde está o corpo de Vakulinchuk (imagem 13). A cena da escadaria de Edessa, com o massacre dos civis pelos cossacos, é extremamente vertical (imagem 14). A verticalização é simbólico-metafórica, significando lutas de classes antagônicas, as de baixo e as de cima, mas, mais do que isso, é uma orientação sensório-corporal fundamental sobre a qual se fundamenta a mensagem do filme.

O filme também é marcado por um ritmo frenético, que está presente em muitas cenas, no gesticular, na fala, nos movimentos dos corpos. Após o vigia sair do dormitório dos marujos, as falas revolucionárias são acompanhadas por gestos frenéticos, com rostos expressivos e mãos gesticulantes. Também há muito ritmo dos corpos na revolta dos marinheiros no navio, na descida da população ao cais para o luto de Vakunlichuk, que recebe mais e mais pessoas, aumentando em número, intensidade e gestos de revolta. Ritmo frenético também marca a famosa na cena da escadaria. As vítimas alvejadas pelos tiros dos cossacos suplicam com braços estendidos, se revoltam com mãos sobre as cabeças. 


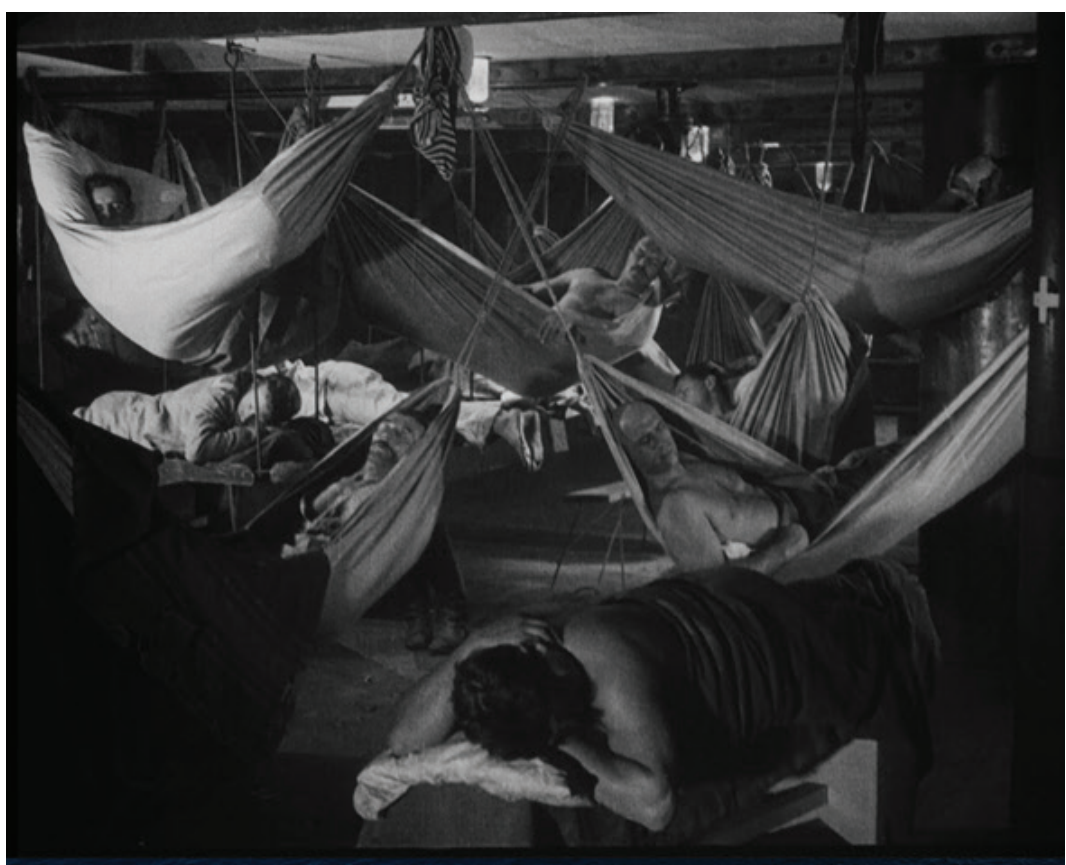

Imagem 10 - Conspirando dos porões

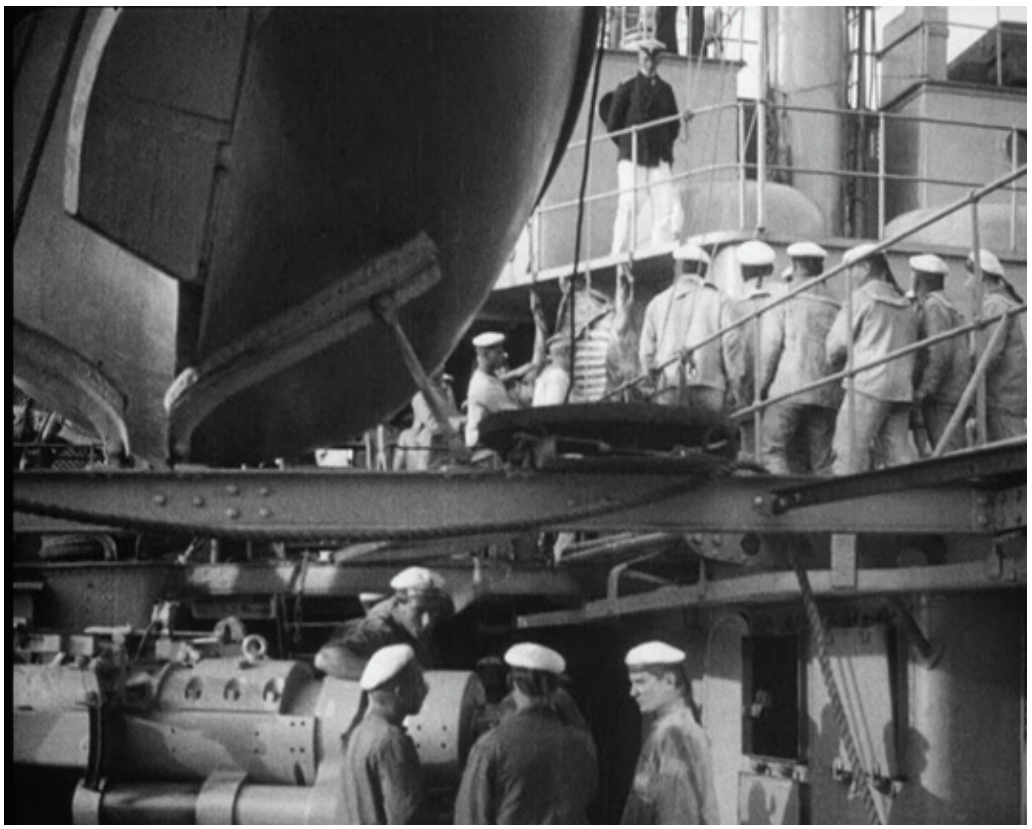

Imagem 11 - Mundo estratificado 


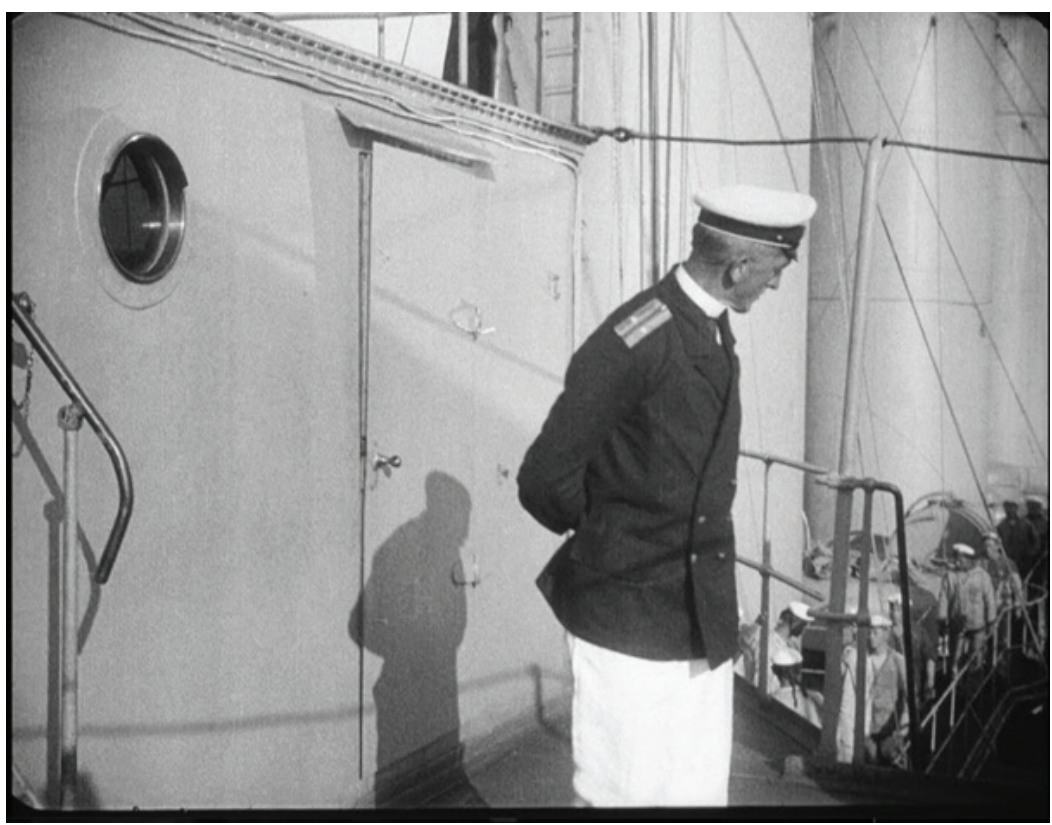

Imagem 12 - Olhando de cima para baixo

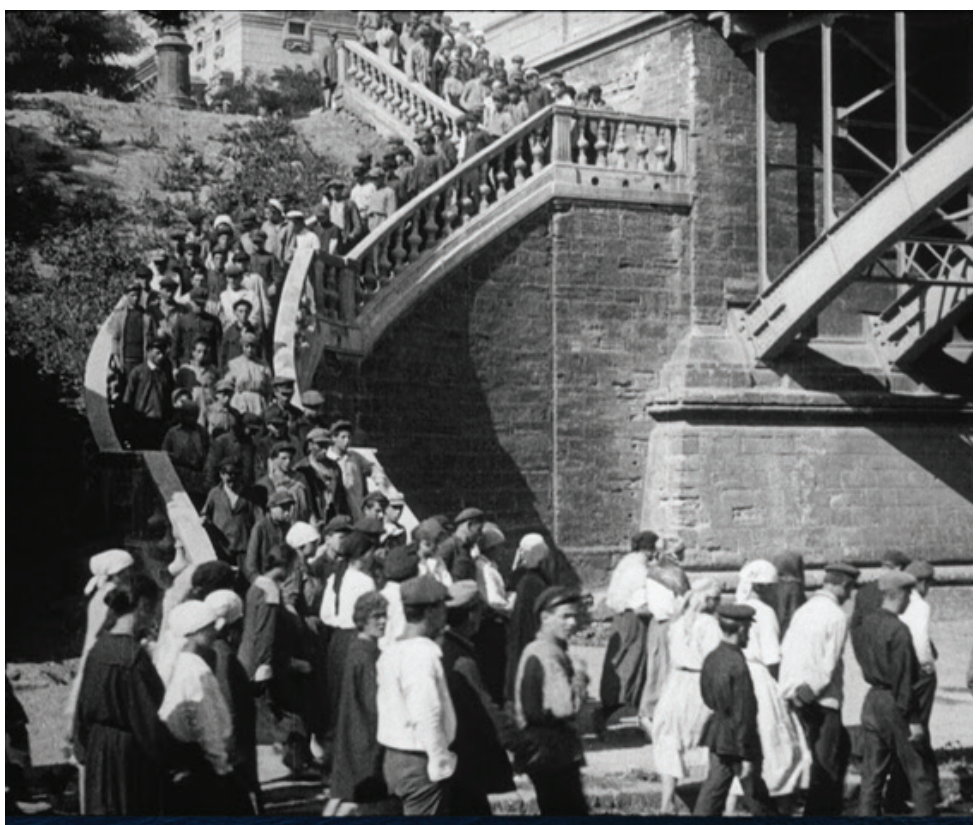

Imagem 13 - Descendo para velar 


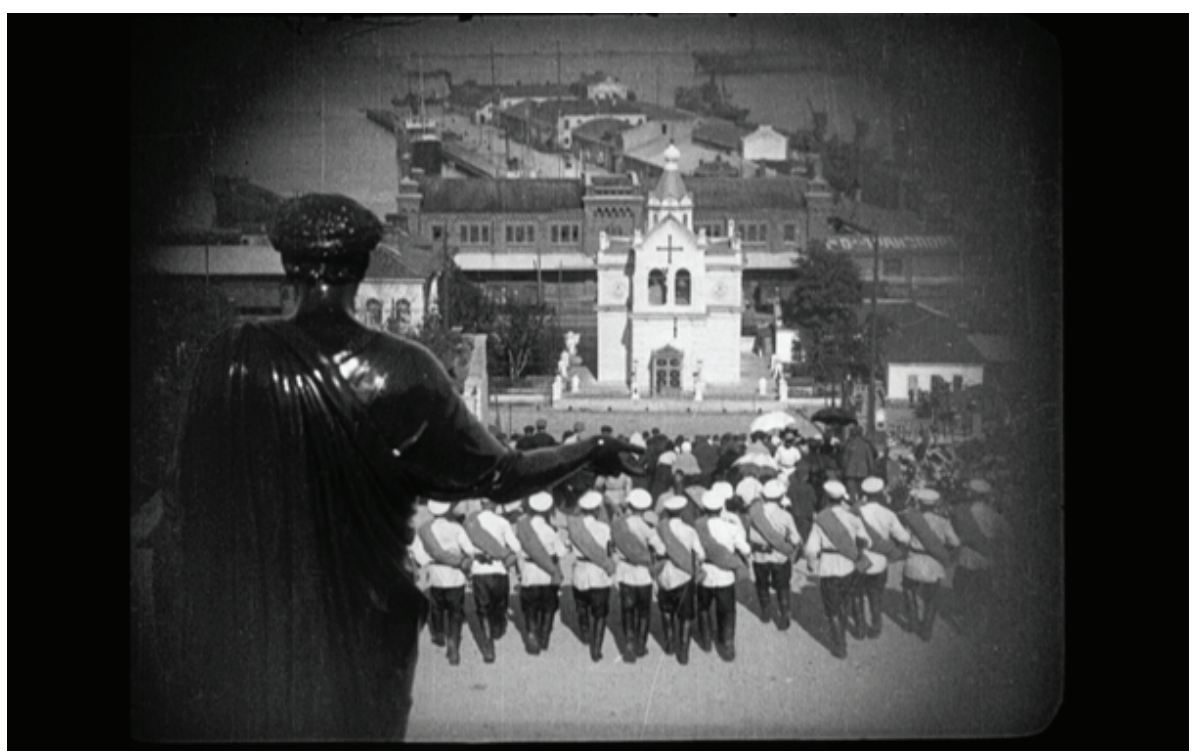

Imagem 14 - Descendo para matar

Há momentos, no entanto, em que o ritmo é quebrado por calmarias, apenas para alimentar o filme com mais imagens primitivas, para potencializar novas cenas rítmicas. Uma delas é a bela cena de transição que marca a madrugada depois da morte do líder dos marinheiros, enquadrando as águas, a neblina no cais do porto, numa luminosidade onírica, em se mergulha numa imagem atemporal. É como se o filme se alimentasse dessa até atemporalidade mítica, bebesse dessas águas profundas, antes de retomar seu drama com o depósito do corpo de Vakulinchuk na barraca para ser velado, como uma espécie de Cristo revolucionário, morto "por um pedaço de pão". Mesmo a retomada do movimento e do ritmo narrativo se faz lentamente, com visitas de curiosos, com a identificação da causa do morto, do choro discreto, da compaixão de anônimos, até os discursos inflamados e gesticulados da massa, atingindo um êxtase revolucionário. Temos outra calmaria no filme antes do êxtase final, no encontro final do encouraçado com a esquadra, que retrata a madrugada insone dos marinheiros. Essa madrugada tensa e sua luta contra o sono, preparam o espectador para o aumento de ritmo, da velocidade dos motores, da preparação das armas, da ereção dos canhões, tudo conduzindo para o grande orgasmo, para o gozo revolucionário, quando os oponentes se saúdam com irmãos. Esse final triunfante contrasta com a noite e com a introspecção que antecipam o êxtase do final. 


\section{Giovanni Felipe Catenaci}

Paulo Augusto de Souza Nogueira

Por fim, queremos destacar o tema da carne podre e o close-up nos vermes que se movimentam nela. O filme usa das estratégias de evocação sinestésica. Os marinheiros protestam contra a carne podre que lhes será servida na sopa, o cozinheiro a cheira constatando seu estado. Como espectadores somos cooptados pelas imagens. Quase podemos sentir o cheiro, a textura e as cores da podridão que indignam os marinheiros. ${ }^{15}$ Mas quando o médico do encouraçado, representado em sua autoridade por seus óculos dobrados, óculos esses que nos conduzem os nossos olhos para a carne eles mesmos tocam, tocam e mostram, então são enquadrados os vermes: seres vivos em movimento, em revolução, em ritmo frenético, vida embutida na morte, em jogos de micro e de macro. Somos conduzidos das estruturas biológicas básicas, das formas de vida elementares, para os movimentos revolucionários de uma sociedade toda.

\section{3 Festa dos mortos, festa dos vivos ${ }^{16}$}

Que Viva México!, cujas tomadas foram filmadas entre 1930 e 1933, representou um marco na reflexão do cinema de Eisenstein, pois a partir de sua estadia no México ele intensificou suas reflexões sobre o pensamento sensorial. O filme foi concluído na União Soviética, a partir de suas filmagens, postumamente. Por isso vamos refletir sobre o elemento sensorial e sua estruturação religiosa em apenas uma cena breve, mas muito importante, "el dia de los muertos". Ela dura não muito mais que 5 minutos e apresenta cenas da tradicional festa mexicana em homenagem aos mortos no Dia de Finados. No México os mortos são lembrados e celebrados pela população com festas, comidas e danças. Eisenstein faz uma leitura muito rica de cenas dessa festa explorando seus aspectos culturais, e seu potencial revolucionário. Mas como o faz tecnicamente? E por meio de que imagens? Ele usa da montagem por oposição dialética, acelerada, contrapondo opostos. $\mathrm{E}$ as imagens que escolhe têm por base elementos arcaicos, do pensamento sensorial. O todo se constitui numa rica combinação de montagem por oposições, combinando temas míticos, em inversão e carnavalização dos temas. Seguem os temas em sequência:

15 Conforme explica Deleuze, "O patético não implica apenas uma mudança no conteúdo da imagem, mas também na sua forma. Com efeito, a imagem deve mudar de potência, passar a uma potência superior. [...]. A inserção do primeiro plano é, uma elevação da imagem ao quadrado" (DELEUZE, 2018, p.63).

16 Cena da cena Dia de los muertos, de Que Viva Mexico!, de Sergei Eisenstein, disponível em https://www.youtube.com/watch?v=LjtgyK014NA acessado em 12 de julho de 2021. 
- Quadros com caveiras e rodas gigantes ou carroceis são mostrados em toda a sequência. As caveiras estão posicionadas em vários lugares no quadro. Há uma ênfase no contraste estático (morte, caveira) com movimento (vida, a brincadeira do parque). (imagens 15 e 16).

- É apresentado o enquadramento do rosto de uma mexicana jovem, sorridente e bonita. Ela é parte do grupo de três jovens que dançam freneticamente em vestidos típicos.

- Elas têm como pares três jovens bailarinos, com máscaras de caveiras. Os quadris das moças e dos rapazes são enquadrados. Há uma erotização nessa dança ritmada com a morte. (imagem 17)

- Um quadro mostra marionetes dançando. Ele é seguido por crianças brincando com marionetes de esqueletos. Vários brinquedos são enquadrados.

- Há crianças-caveira e caixões de brinquedo.

- Crianças comem caveiras de açúcar. (imagem 18)

- Segue-se um carnaval, uma masquerade de caveiras.

- As três moças reaparecem com seus quadris rebolantes. Uma banda macabra de bonecos aparece tocando.

- Quando um casal se beija ele é sobreposto por uma caveira em closeup. Sobreposição de morte e vida.

- Segue-se um quadro com uma caveira aristocrata, com cartola, terno e bengala, num caso claro de inversão carnavalizante (imagem 19). A ela se segue um camponês-caveira, um guarda e um cavaleiro, que só se pode ver pelas esporas nos calcanhares esqueléticos (pars pro toto).

- Um primeiro jovem em close-up tira a máscara de caveira e ri. Mais quatro jovens fazem a mesma coisa. Um grupo de crianças tiram suas máscaras e riem.

- Na última cena um menino em duração maior do quadro é mostrado com a máscara e por fim a tira em close-up.

Estes temas todos, que são apresentamos em sequências rápidas de quadros, aparecem em pouco mais de 5 minutos, compondo uma parte frenética do filme. A montagem propõe ritmo acelerado, que é dado não só na rapidez da montagem, como também no tema inicial das mulheres e dos rapazes dançantes, que movem eroticamente seus quadris. Além do ritmo, os quadros todos propõem jogos de contrários, em dialética fundamental de vida versus morte: caveiras (mortos imóveis) contrastam com rodas-gigantes e carroceis girando, moças sensuais dançando com jovens mascarados de caveiras, crianças e brinquedos infantis com os temas da morte, crianças comendo caveiras de açúcar, agitação e praça movimentada versus o silêncio e inércia da comunidade dos mortos. 


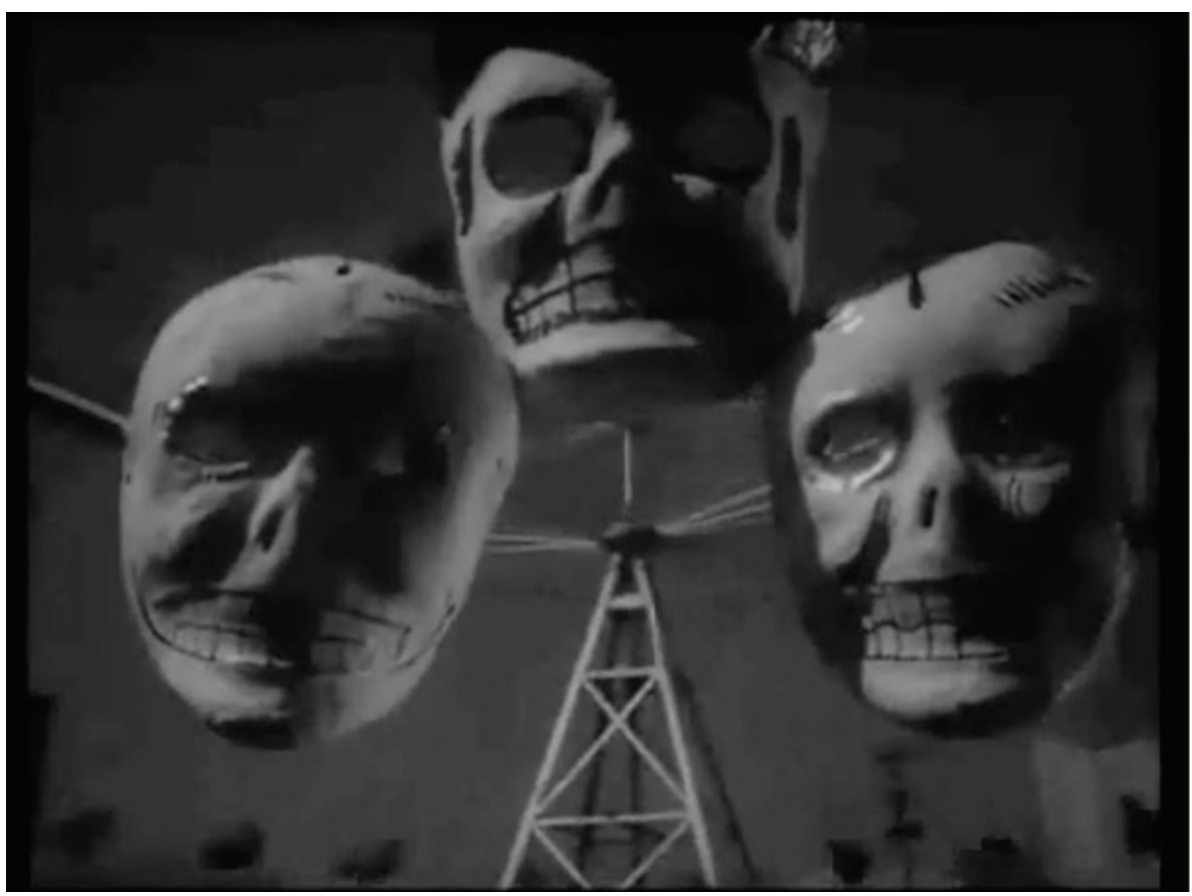

Imagem 15 - Caveiras e roda gigante

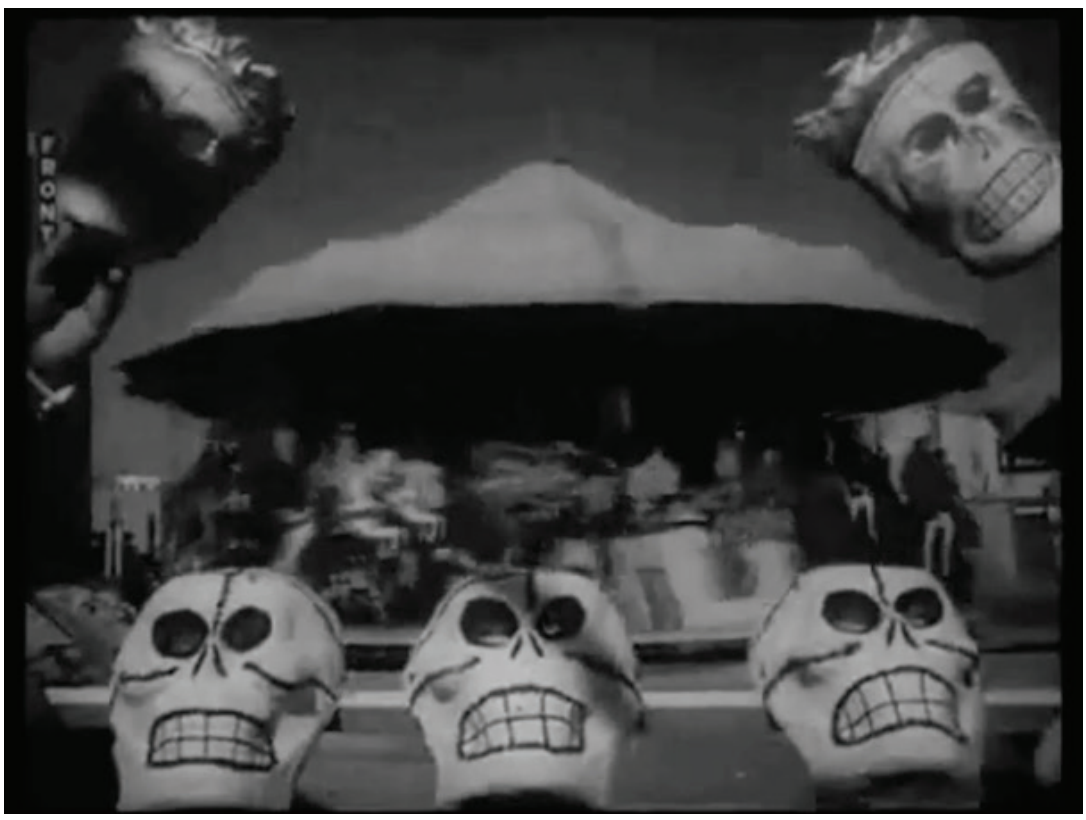

Imagem 16 - Repouso e movimento 


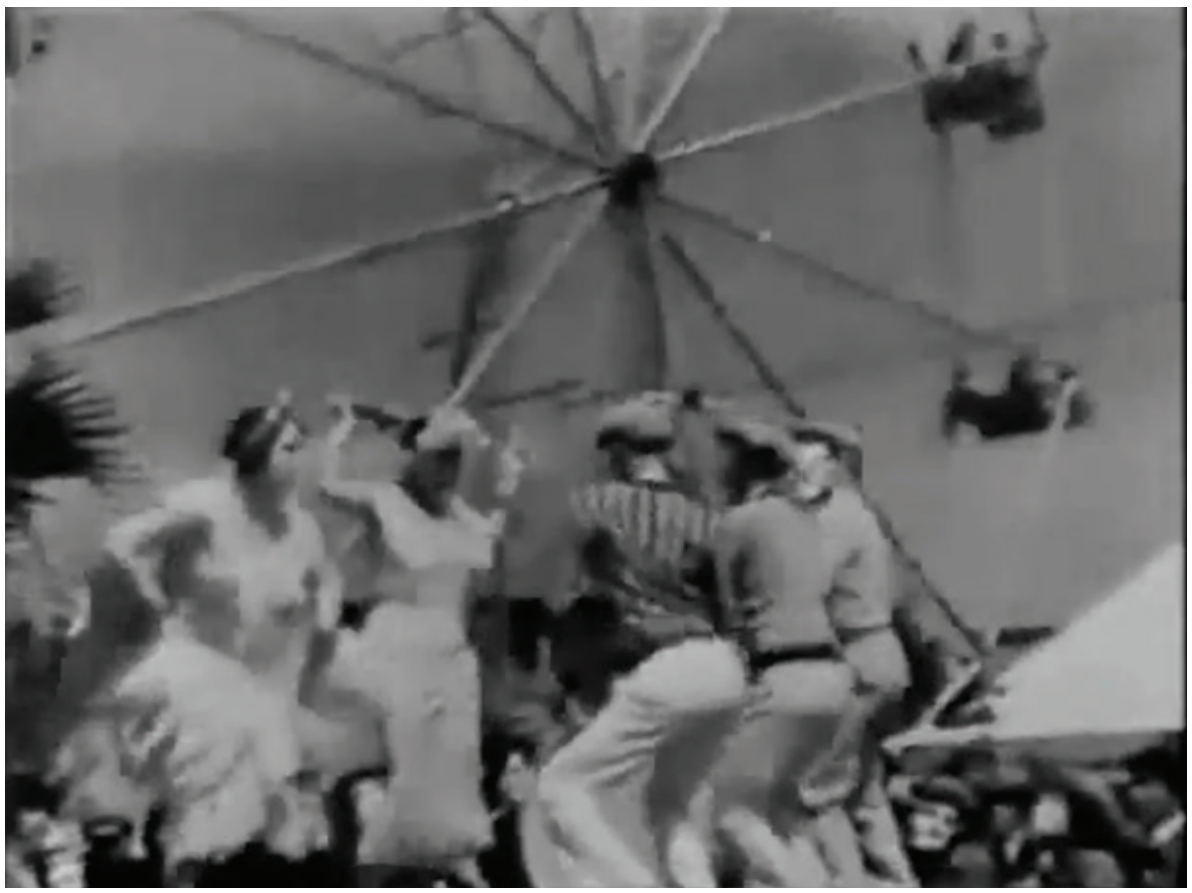

Imagem 17 - Dança macabra

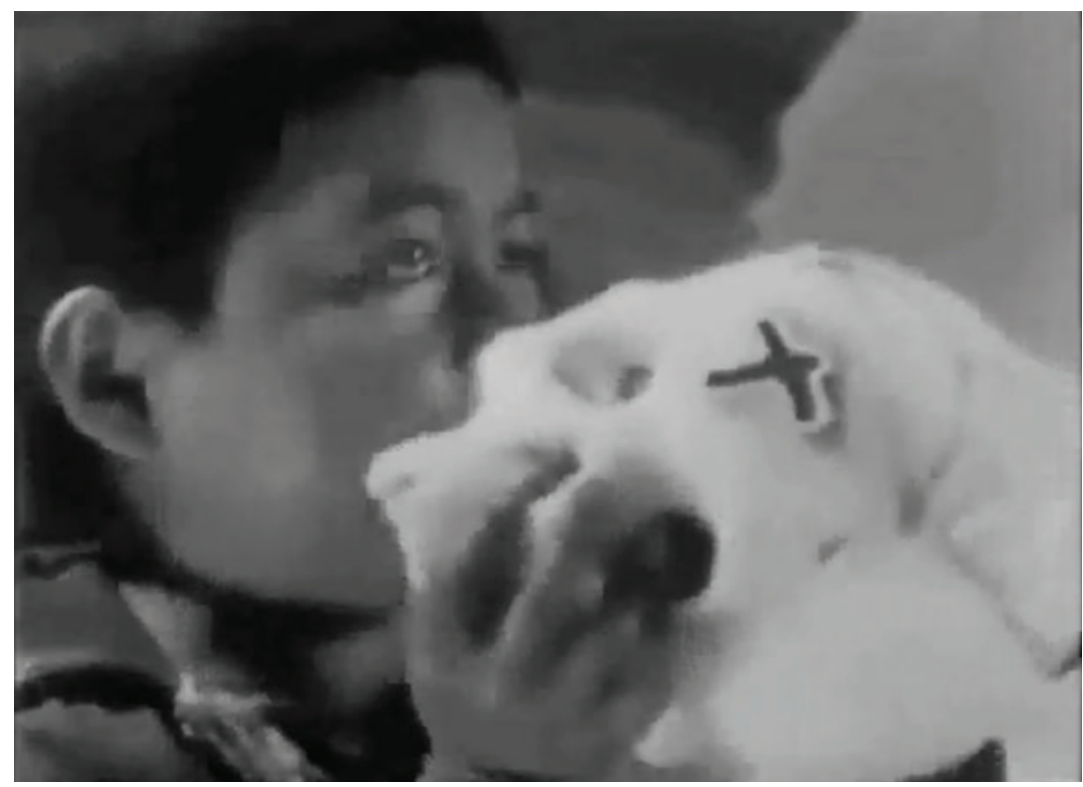

Imagem 18 - Comendo a morte 


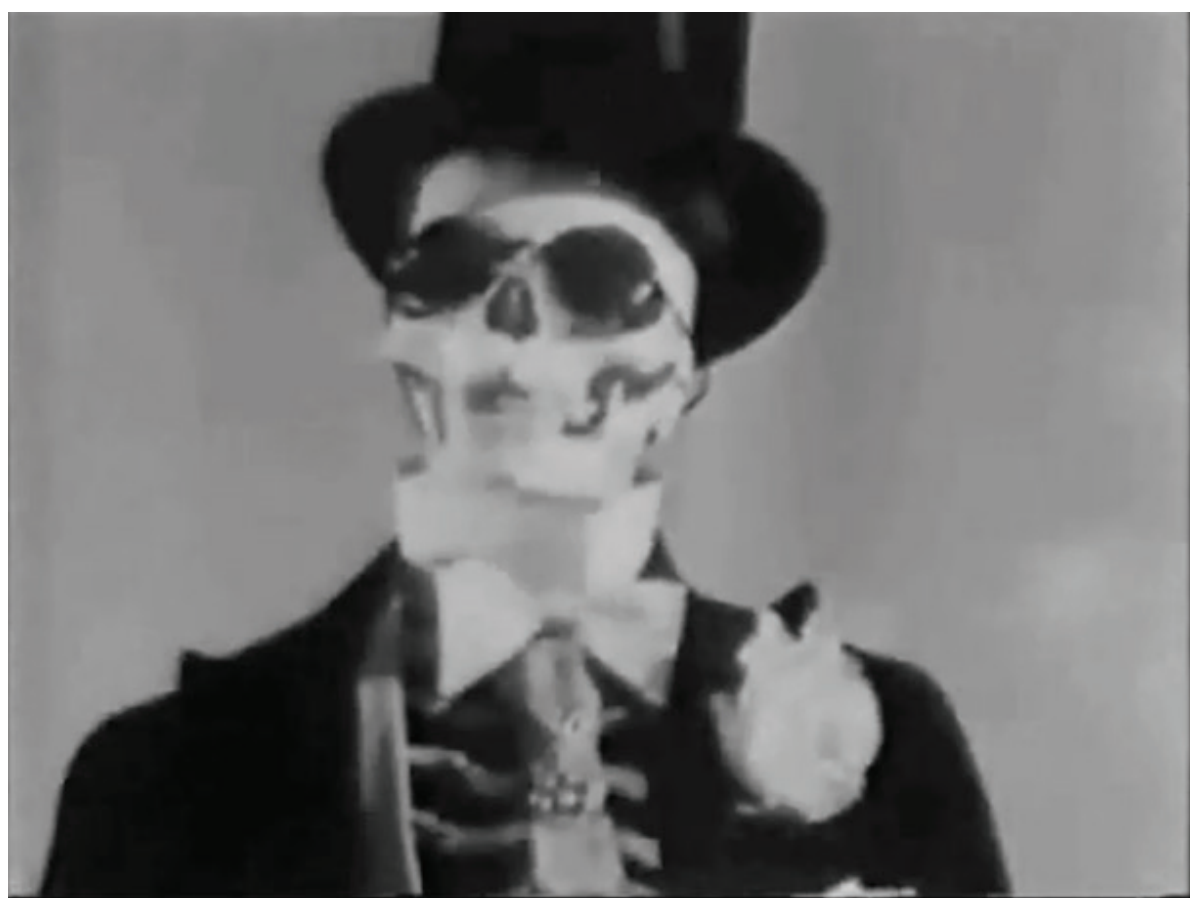

Imagem 19 - Carnaval

Temos aqui um jogo vanguardista, revolucionário, na metáfora da festa dos mortos como representação da dinâmica, irreverência e instabilidade das formas sociais e políticas, mas que para colocá-lo em ação recorre a estruturas mitopóeticas arcaicas, sensoriais, ligadas ao corpo e a suas projeções. Erotismo e morte, infância e morte, comida e morte, morte como espaço para ironizar status social, tudo isso permite uma profunda inversão carnavalizante - para emprestar o conceito bakhtiniano - do mundo e de suas estruturas.

\section{Considerações finais}

Após este longo trajeto, temos condições de retomar a primeira pergunta levantada no início deste texto. Assim afirmamos que o cinema pensa e faz pensar através de "socos na mente", eis o "cine-murro", como diria Eisenstein (DELEUZE, 2018, p.71). Ou se preferirem, para ficar com Deleuze, noochoques - este é o nome dessa "outra violência de uma imagemmovimento desenvolvendo suas vibrações em uma sequência móvel que mergulha em nós" (DELEUZE, 2018b, p.228-229). Em sotaque kantiano, 
a nomeamos de "sublime", imagem formada naquele momento em que "a imaginação sofre um choque que a leva ao seu limite, e força o pensamento a pensar o todo enquanto totalidade intelectual que ultrapassa a imaginação" (DELEUZE, 2018b, p.229).

É isso, aliás, que levará Deleuze afirmar que o cinema surge e se constitui enquanto cinema do pensamento. Em Cinema II, A imagem-tempo [1985], alinhando-se às críticas de Antonin Artaud, Deleuze dirá que é justamente esta uma das grandes funções do cinema: fazer pensar. Em suas palavras, "É isso a onda de choque ou a vibração nervosa, tal que não se pode mais dizer 'vejo, ouço', mas SINTO [...]. É o conjunto dos harmônicos agindo sobre o córtex que faz nascer o pensamento, o PENSO cinematográfico" (DELEUZE, 2018b, p.230).

Lembramos novamente de Bergson agora, a fim de podermos constatar que o que se revela aqui é nada menos que o trajeto da percepção à ação, tal como disposta através das explicações iniciais acerca da estrutura sensóriomotora dos organismos. E o que vemos é que da sensação à percepção temos o choque, e posteriormente a este choque temos a gênese de um pensamento ainda desconhecido. Conforme atestam as palavras do próprio Deleuze,

\footnotetext{
"se é verdade que o pensamento depende de um choque que o faz nascer (o nervo, a medula), ele só pode pensar uma única coisa, o fato de que ainda não pensamos, a impotência tanto para pensar o todo como pensar a si mesmo, estando o pensamento sempre petrificado" (DELEUZE, 2018b, p.244).
}

De outro modo, o que temos exposto neste bergsonismo cinematográfico, é que é precisamente a fissura entre a sensação do choque $e$ uma respectiva reação - ou seja, a hesitação tributária da indeterminação -, o começo do pensar. De tal maneira que somos levados a concluir que é somente quando se depara com sua extremidade, e, por conseguinte começa a se desligar de sua motricidade orgânica e habitual de conservação, que o pensamento se abre a vidência abismal de sua origem. Não obstante, recorrendo à montagem dialética de Eisenstein, destacamos que a religião é um componente indispensável neste processo germinativo do pensamento.

Com destaque à sua teoria da relação entre forma e conteúdo, entre estruturas sensoriais, arcaicas, e elementos projetivos, revolucionários, descrevemos como o cinema fundamenta a transformação do mundo na dinâmica de materiais provindos das percepções mais fundamentais dos seres 


\section{Giovanni Felipe Catenaci}

Paulo Augusto de Souza Nogueira

humanos e da vida biológica: ritmo, gesto, sons, movimentos, sinestesia. Estes signos combinados - abundantes na religião, diga-se de passagem -, emprestam ao cinema - uma forma de arte única, sincrética - o poder de promover transformação, por meio do êxtase, da catarse, e do pensamento propriamente dito.

O que ocorre é que o hábito foi ferido, o edifício sensório-motor da percepção curto-circuitado pela a violência de um relâmpago vermelho. Um murro soviético, lhe atingiu estremecendo-o por inteiro. Nenhuma lembrança fácil à mão é capaz de dar vazão a uma reação consentida agora. Apenas o clarão estrondoso, o choque e o retumbante silêncio. A origem do pensamento é o fato de que ele não pensa ainda... Forçar na mente e no corpo este estádio de perturbação é aquilo que garante a Eisenstein a oportunidade de levar a cabo sua missão de engenheiro de uma nova metafísica revolucionária. Colocar a Rússia diante do impensável, a fim de fazê-la pensar, e assim, agir como nunca.

Enfim, a teoria e a prática de cinema do diretor russo, tal como por nós descrita neste artigo, serve de corretivo para nossas visões da arte e da religião que tendem a relegá-las a superestruturas, a âmbitos complementares das questões centrais da sociedade, como se arte e religião estivessem dissociadas da vida. Ao contrário, a arte e a religião se encontram imbricadas no movimento dinâmico dos corpos, em nossas conexões e projeções fundamentais no mundo. Qualquer processo de transformação cultural e social beberá, portanto, dessas águas profundas.

\section{Bibliografia}

BERGSON, Henri. Evolução criadora. São Paulo: Martins Fontes, 2019.

BERGSON, Henri. Matéria e Memória: Ensaios sobre a relação do corpo com o espírito. São Paulo: Martins Fontes, 2011.

BULGAKOWA, Oksana. From expressive movement to the "basic problem". The VygotskyLuria-Eisensteinean theory of art, in Yanitsky, A.; van der Veer, R.; Ferrari, M. (eds.). The Cambridge Handbook of Cultural-historical Psychology. Cambridge: Cambridge University Press, 2014, p.423-448.

BULGAKOWA, Oksana. From stage to brain: Montage as a new principle of scientific narrative. Sign Systems Studies 41(2/3), 2013, p. 200-218.

DELEUZE, Gilles. Cinema 1 - A imagem-movimento. São Paulo: Editora 34, 2018.

DELEUZE, Gilles. Cinema 2: Imagem-tempo. São Paulo: Editora 34, 2018b. 
EISENSTEIN, Sergei. A forma do filme. Rio de Janeiro: Zahar, 2002.

EISENSTEIN, Sergei. The Psychology of Art. Journal of Russian \& East European Psychology, 51-5-6, 2013, p.192-199.

IVANOV, V. V. The Grundproblem in the Theory of Art. Journal of Russian \& East European Psychology, 51:5-6, 2013, p. 179-191.

MORIN, Edgar. O cinema ou o homem imaginário. Ensaio de antropologia sociológica. São Paulo: É Realizações, 2014.

TYLOR, Edward B. Primitive Culture. Researches into the Development of Mythology, Philosophy, Religion, Language, Art and Custom. Vol. 1\&2. Mineola, New York: Dover Publication, 2016 (Reprint of the $2^{\text {nd }}$ edition of 1873).

VASSILIEVA, Julia. The Eisenstein-Vygotsky-Luria Collaboration. Triangulation and Third Culture Debates. Projections, vol. 13, Issue 1, 2019, p. 23-44.

Submetido em: 26-7-2021

Aceito em: 29-9-2021 